\title{
A NEW APPROACH TO THE LEGALITY OF FRANCHISING TIE-INS
}

The tying doctrine of antitrust law has been the subject of frequent spirited criticism by scholars of diverse disciplines. Economists and economics-oriented legal scholars in particular have treated tying doctrine with notorious disapproval. ${ }^{1}$ They have challenged the fundamental assumptions of the tying doctrine, labelling them "indefensible," 2 "false," 3 and "arbitrary." 4 Other legal scholars, although quick to criticize judicial formulations of the doctrine, have attempted to defend the doctrine on the ground that it serves to advance such traditional antitrust values as free access to markets and consumer sovereignty. ${ }^{5}$ Caught in this crossfire are the courts which, though cognizant of the basic soundness of the economic analysis, shy away from abandoning the convenient per se prohibition against tying, in order to avoid what Justice

I See R. Bork, The Antrtrust Paradox 365-81 (1978); R. Posner, ANTItrust Law 171-84 (1976); G. Hale \& R. Hare, Market Power: Size and Shape UNDER THE Sherman ACT 53 (1958); Austin, The Individual Coercion Doctrine in Tie-In Analysis: Confusing and Irrelevant, 65 CALrF. L. Rev. 1143 (1977); Baker, The Supreme Court and the Per Se Tying Rule: Cutting the Gordian Knot, 66 VA. L. Rev. 1235 (1980); Baldwin \& McFarland, Tying Arrangements in Law and Economics, 8 ANTITRUsT BuLL. 743 (1963); Bowman, Tying Arrangements and the Leverage Problem, 67 YALE L.J. 19 (1957); Burstein, A Theory of Full-Line Forcing, 55 Nw. U.L. Rev. 62 (1960); Director \& Levi, Law and the Future: Trade Regulation, 51 Nw. U.L. Rev. 281 (1956); Edwards, Economics of "Tying" Arrangements: Some Proposed Guidelines for Bank Holding Company Regulation, 6 ANTITRUST L. \& Econ. Rev. 87 (No. 3, 1973); Ferguson, Tying Arrangements \& Reciprocity: An Economic Analysis, 30 L. \& Contemp. Pros. 552 (1965);

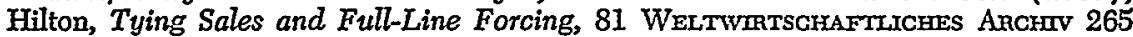
(1958); Markovits, Tie-ins, Reciprocity, and the Leverage Theory (pts. 1 \& 2), 76 YALE L.J. 1397 (1967), 80 YALE L.J. 195 (1970); Markovits, Tie-ins and Reciprocity: A Functional, Legal, and Policy Analysis, 58 TEx. L. REv. 1363 (1980); Pearson, Tying Arrangements and Antitrust Policy, 60 Nw. U.L. Rev. 626 (1965); Stigler, United States v. Loew's Inc.: A Note on Block-Booking, 1963 Sup. Cr. REv. 152. Burstein, supra, and Ferguson, supra, soundly criticize tying doctrine but would retain a per se rule. See note 106 infra \& accompanying text.

2 Baker, supra note 1, at 1317.

3 Bowman, supra note 1 , at 20.

4 Id. 33.

5 See C. Kaysen \& D. Turner, Antimust Poritcy 157 (1959); L. Sulitivan, HANDBOOK OF THE LAW OF ANTtTrust 431-72 (1977); Bauer, $A$ Simplified Approach to Tying Arrangements: A Legal and Economic Analysis, 33 VAND. L. Rev. 283 (1980); Turner, The Validity of Tying Arrangements Under the Antitrust Laws, 72 Harv. L. Rev. 50 (1958); Note, The Logic of Foreclosure: Tie-in Doctrine after Fortner v. U.S. Steel, 79 YALE L.J. 86 (1969) [hereinafter cited as Logic of Foreclosure]. 
Marshall might call a "ramble through the wilds of economic theory." 8

This Comment represents another attack on the tying doctrine. Unlike previous commentaries, however, this Comment perceives in the field of trademark franchising a remarkable confluence of otherwise divergent values. Both economic efficiency and the traditional social goals of antitrust can be served by permitting tying in trademark franchising, except where the effect of tying would be to raise a barrier to future entry into the market.

The primary purpose of this Comment is to develop an analytical framework and legal test that facilitates judicial use of economic analysis in franchise tying cases. This Comment offers a test that is no less, and perhaps more, certain and manageable than the present per se rule. Use of this test would let society reap the full benefits of trademark franchising without imposing any significant additional burden on the courts.

In part $I$, this Comment briefly outlines the tying doctrine in general and as applied to franchise tying. Part II discusses the nature and effects of trademark franchising. Part III synthesizes the economic analysis of tying with the principles of trademark franchising. Part IV assesses use of the present per se rule in the franchise tying context. Finally, part $\mathrm{V}$ presents and discusses a general rule of legality for tying in trademark franchising.

\section{Basic Tying Doctrine in the Courts}

A tying arrangement is characterized by a seller's refusal to sell a product except on the condition that the buyer also purchase a different product. ${ }^{7}$ The first product is referred to as the tying product, the second as the tied product.

6 United States v. Topco Assocs., 405 U.S. 596, 610 n.10 (1972). In Moore v. Jas. H. Matthews \& Co., 550 F.2d 1207, 1213 (9th Cir. 1977), the court stated:

The clear implication from a purely economic standpoint is that tie-ins should be considered on a case-by-case basis because they are not inherently detrimental. They can in fact be beneficial.

The difficulty with adopting such an approach is well-recognized and it derives from the nature of courts and the costs of judicial enforcement. The problem stems from the unwillingness, if not the inability, of courts to undertake complex economic decision making in the face of economic indeterminancy and over-crowded court calendars.

7 Northern Pac. Ry. Co. v. United States, 356 U.S. 1, 5-6 (1958). A tying arrangement may also be created from an agreement that the buyer not purchase what would be the tied product from anyone but the seller of the tying good. Id. This Comment is not concerned with such arrangements. 
The Supreme Court has treated tying arrangements as per se illegal under the Sherman and Clayton Acts ${ }^{8}$ because, in the Court's view, these arrangements "serve hardly any purpose beyond the suppression of competition." $"$ The hostility of the courts to tying is based on three concerns. First, tying may enable a seller to extend his market power over the tying product into the market for the tied product. ${ }^{10}$ Such use of a tie-in to extend market power is frequently referred to as "leverage." 11 Second, tying doctrine is intended to protect buyers against "the coerced sacrifice of alternatives" to the tied product.12 Third, courts have expressed a belief that tying limits access of competing suppliers to the tied product market. ${ }^{13}$ These last two concerns taken together evince a desire by the courts that competition in the sale of each product be "on the merits." 14

Characterization of the tying doctrine's legal application as a "per se" prohibition is somewhat misleading because a plaintiff must do more than merely show the existence of a tying arrangement in order to prevail.15 The Supreme Court has stated that an illegal tie-in will be held to exist whenever it is shown that (1) the tying

8 Tying arrangements have been found to violate section one of the Sherman Act, 15 U.S.C. $\$ 1$ (1976), which provides in relevant part: "Every contract, combination .... or conspiracy, in restraint of trade or commerce among the several States.... is hereby declared to be illegal."

Tying arrangements have also been found to violate section three of the Clayton Act, 15 U.S.C. $\$ 14$ (1976), which explicitly prohibits certain types of tying arrangements and applies a different legal standard than section one of the Sherman Act. Section three, however, is limited to cases in which the tying good is "goods, wares, merchandise, machinery, supplies, or other commodities." Id. Since this Comment is concerned with tie-ins in trademark franchising, in which case the tying product is a trademark, the discussion does not involve the Clayton Act.

9 Northern Pac. Ry. Co. v. United States, 356 U.S. 1, 6 (1958) (quoting Standard Oil v. United States, 337 U.S. 293, 305-06 (1949)).

$10 I d .6$.

11 See, e.g., Bowman, supra note 1, at 20.

12 Turner, supra note 5, at 60 . See United States v. Loew's, Inc., 371 U.S. 38, 44-46 (1962); Northern Pac. Ry. Co. v. United States, 356 U.S. 1, 6 (1958).

13 See United States v. Loew's, Inc., 371 U.S. 38, 44-46 (1962); Northern Pac. Ry. Co. v. United States, 356 U.S. 1, 6 (1958). Some commentators believe that free access is the central concern behind the tying doctrine. See Tumer, supra note 5, at 60-62; Logic of Foreclosure, supra note 5.

14 Northern Pac. Ry. Co. v. United States, 356 U.S. 1, 6, 10-12 (1958) (quoting Times-Picayune Publ. Co. v. United States, 345 U.S. 594, 605 (1953)). See Baker, supra note 1, at 1268; Turner, supra note 5, at 60.

15 The inconsistency of the Court's "per se" rule with the strict definition of "per se" has caused confusion among both laymen and lawyers. For two attempts to dispel this confusion see Baldwin \& McFarland, Some Observations on 'Per Se' and Tying Arrangements, 6 ANrrrnust Bulc. 433 (1961); Singer, Market Power and Tying Arrangements, 8 ANTrTRust BuLc. 653 (1963). 
and tied products are separate and distinct; ${ }^{10}$ (2) the seller has "sufficient economic power with respect to the tying product to appreciably restrain competition in the market for the tied product," 17 and (3) "a 'not insubstantial' amount of interstate commerce is affected." 18 Some lower federal courts also require the plaintiff to show that he was coerced by the seller into buying the tied product. ${ }^{19}$

In addition to requiring proof of these elements, the "per se" rule is also subject to certain defenses. These defenses consist of business or economic justifications for the illegal tying arrangement. One such justification is the new industry defense, which saves a tie-in if it is shown to be necessary to protect the industry during the early stages of its development. ${ }^{20}$ Another justificationand one that is particularly applicable to franchising tie-ins-is the goodwill or quality control defense. Under this defense, a tie-in will be permitted if it is necessary to protect the goodwill associated with a tying good and no alternative quality-control arrangement, such as specifying the characteristics of the products to be used in conjunction with the tying, good is practicable. ${ }^{21}$ For example, a franchisor may require that a franchisee purchase certain products from him as a condition of the franchise agreement if the use of an inferior product would damage the goodwill of the franchisor's trademark and if the tied product is too complex to be suitable for

16 See, e.g., Fortner Enterprises, Inc. v. United States Steel Corp., 394 U.S. 495, 507 (1969).

$1 \tau$ Northern Pac. Ry. Co. v. United States, 356 U.S. 1, 6 (1958).

18 Id. 6 (citing International Salt Co. v. United States, 332 U.S. 392 (1947)). This requirement may be meaningless. Courts have focused on dollar amounts rather than market percentages in assessing the significance of the amount of commerce affected by the tie-in. Tying arrangements involving as little as $\$ 40,000$ and $\$ 50,000$ worth of sales in the tied product have been determined to be "not insubstantial." Levy, Trademark Franchising and Antitrust: The Two Product Rule for Tying Arrangements, 69 Trademark REP. 41, 57 (1979). The Supreme Court has found tied sales of as little as $\$ 60,800$ "not insubstantial." See United States v. Loew's, Inc., 371 U.S. 38, 49 (1962).

19 See, e.g., Photovest Corp. v. Fotomat Corp., 606 F.2d 704, 723 (7th Cir. 1979), cert. denied, 445 U.S. 917 (1980); Bogosian v. Gulf Oil Corp., 561 F.2d 434, 450-51 (3d Cir. 1977), cert. denied, 434 U.S. 1086 (1978); Ungar v. Dunkin' Donuts of Am., Inc., 531 F.2d 1211, 1223-24 (3d Cir.), cert. denied, 429 U.S. 823 (1976); Capital Temporaries, Inc. v. Olsten Corp., 506 F.2d 658, 661-63 (2d Cir. 1974). But see 9 Cons. L. Rev. 164, 170 (1976) (arguing that "[t]he presence or absence of coercive sales tactics is not related to the economic evils that tying law seeks to curb."). See generally Austin, supra note 1.

${ }^{20}$ See United States v. Jerrold Elec. Corp., 187 F. Supp. 545 (E.D. Pa. 1960), aff'd per curiam, 365 U.S. 567 (1961).

21 See, e.g., Carpa, Inc. v. Ward Foods, Inc., 536 F.2d 39, 46-47 (5th Cir. 1976). The court suggested that the "new industry" and "quality control" defenses are "indistinguishable" in that both are without force if a competitor can supply the tied items in the same quality class as those supplied by the seller. Id. 47 . 
a specifications list. ${ }^{22}$ Unfortunately for franchisors, the scope of this defense has been minimized by the courts. ${ }^{23}$

The tying doctrine has generally been applied to franchising in cases in which the franchisor's licensing of his trademark or name was conditioned on agreement by the prospective franchisee to purchase additional products from him..$^{24}$ In these cases, the courts have differed greatly in their treatment of the elements of the tying offense. Some courts have held that the trademark constitutes a distinct tying product separate from the tied goods; other courts have viewed the trademark and tied product as a single package and thus declined to find any tying arrangement. ${ }^{25}$ Whereas several courts have inferred the requisite economic power in the tying product from the trademark or name, ${ }^{26}$ other courts have required a more detailed inquiry into the franchisor's market power. ${ }^{27}$ Courts which have required proof of individual coercion of franchisees have done so under what frequently seem to be differing, if not conflicting, standards of proof. ${ }^{28}$ As is true of tie-in cases generally, however, the substantiality of the amount of commerce affected has rarely, if ever, been an important issue. ${ }^{29}$

\section{The Nature and Effects of Franchising}

\section{A. The Nature of Franchising}

The distinguishing characteristic of trademark franchising is a license from the owner of a trademark or a trade name to the

22 See Siegel v. Chicken Delight, 448 F.2d 43, 51 (9th Cir. 1971), cert. denied, 407 U.S. 955 (1972).

23 E. Kintiner, 2 FederaI ANTitrust Law $\$ 10.62$, at 258 (1980).

24 See, e.g., Photovest Corp. v. Fotomat Corp., 606 F.2d 704, 724-25 (7th Cir. 1979), cert. denied, 445 U.S. 917 (1980); Northern v. McGraw Edison Co., 542 F.2d 1336 (8th Cir. 1976), cert. denied, 429 U.S. 1097 (1977); Carpa, Inc. v. Ward Foods, Inc., 536 F.2d 39 (5th Cir. 1976); Siegel v. Chicken Delight, Inc., 448 F.2d 43 (9th Cir. 1971), cert. denied, 405 U.S. 955 (1972).

25 See, e.g., Principe v. McDonald's Corp., 631 F.2d 303 (4th Cir. 1980); Kugler v. Aamco Automatic Transmissions, Inc., 460 F.2d 1214, 1215-16 (8th Cir. 1972); In re 7-Eleven Franchise Antitrust Litigation, [1974-2] Trade Cas. II 75,429 (N.D. Cal. 1974).

26 See, e.g., Warriner Hermetics, Inc. v. Copeland Refrigeration Corp., 463 F.2d 1002 (5th Cir. 1972); Siegel v. Chicken Delight, Inc., 448 F.2d 43 (9th Cir. 1971), cert. denied, 405 U.S. 955 (1972). See also In re Chock Full O' Nuts, 83 F.T.C. 573 (1973).

27 See note 194 infra.

28 Compare, e.g., Bogosian v. Gulf Oil Corp., 561 F.2d 434 (3d Cir. 1977), cert. denied, 434 U.S. 1086 (1978) and Ungar v. Dunkin' Donuts of Am., Inc., 531 F.2d 1211 (3d Cir.), cert. denied, 429 U.S. 823 (1976) with Capital Temporaries, Inc. v. Olsten Corp., 506 F.2d 658, 661-63 (2d Cir. 1974) and Krehl v. Baskin-Robbins Ice Cream Co., 78 F.R.D. 108 (C.D. Cal. 1978). See also notes 186-89 infra \& accompanying text.

29 See Harkins, Tying and the Franchisee, 47 ANrrrnost L.J. 903, 905 (1979). 
franchisee permitting the licensee to sell, distribute, or manufacture products or services under the trademark (or trade name)..$^{30}$ Use of the trademark permits the franchisee to benefit from the consumer goodwill associated with it.

In order to ensure that the new franchisee does not damage this accumulated goodwill, the franchisor will usually require the franchisee to maintain certain quality standards, and will monitor the franchisee's performance of the agreement.31 In turn, the franchisor often provides the franchisee with certain services such as advertising and technical training. ${ }^{32}$ The franchisee's position thus falls somewhere between independent businessman and employee: the franchisee sacrifices some degree of control over the conduct of his business in order to obtain the benefit of the goodwill associated with the trademark and whatever other services the franchisor agrees to provide.

\section{B. The Economic Basis of Franchising}

Franchising has undergone rapid and consistent growth since the end of World War II. ${ }^{33}$ In 1969, franchised outlets had retail sales of 90 billion dollars, which represented more than twenty percent of all United States retail sales. ${ }^{34}$ By 1972, annual sales had increased to 134 billion dollars, representing twenty-five percent of all retail sales. ${ }^{35}$ In 1980, franchised retail outlets had sales of 295 billion dollars, thirty-one percent of all retail sales. ${ }^{36}$

The rapidness of this growth stems from franchising's usefulness as a means for a producer to gain some significant measure of control over the distribution of his product and yet retain some

30 See genetally G. Guickican, 15 Business Organizations $\$ 2.01$ (1980).

Professor Sullivan distinguishes several different types of franchising arrangements, only one of which permits the franchisee to operate under the franchisor's trademark. L. SulinvaN, supra note 5, at 399-401. This type of franchising he refers to as "a franchise in the strictest sense." Id. 401. The term "franchising," as used in this Comment, refers to precisely this type of arrangement. This definition of franchising is in accord with that used by scholars who have studied franchising. See U. Ozanne \& S. Hunt, Senate Select Commattee on Smant Business, 92D Cong., 1st Sess., The Economic Emfects of Franchusing 26 (Comm. Print 1971); L. Rubin, A Theory of Franchising (1973) (unpublished Ph.D. dissertation in the University of Pennsylvania's Van Pelt Library).

31 See G. Gitckman, supra note 30.

32 Id.

33 L. Rubin, supra note 30 , at 2.

34 Note, Regulation of Franchising, 59 Mins. L. REv. 1027, 1028 n.9 (1975). $35 I d$.

36 Bureau of Industrial Economis, U.S. Dept. of Commerce, Franchising IN THE ECONOMY 1979-198I, at 1-10 (1981). 
of the advantages of selling his product through a system of independent retailers. ${ }^{37}$ Franchising thus represents a step away from a system of market transactions among producers, wholesalers, and retailers, and a step towards full vertical integration.

A complete discussion of the economics of vertical integration into distribution is beyond the scope of this Comment. It is sufficient for our purposes to note that several reasons have been suggested. Whereas some authors have explained the phenomenon in terms of technological economies, ${ }^{38}$ and others have noted the importance of managerial economies and economies in advertising, ${ }^{39}$ Professor Oliver Williamson has emphasized a third factor: vertical integration is a means of avoiding the transaction costs of contracting between independent firms by conducting such transactions within a single firm. ${ }^{40}$ Transaction cost savings can be attained independently of technological and managerial economies and may explain cases of vertical integration where these economies do not exist. ${ }^{4 I}$

The transaction cost model helps explain franchising's appeal for many producers. Franchising is most likely to occur when the supplier's product is the subject of extensive consumer comparison shopping and when the consumer's confidence in the retailer and the retailer's supply of various services are important factors in the decision to buy. ${ }^{42}$ In such circumstances, the producer will normally seek some control over the retailing of his product in order to build up and maintain customer loyalty. ${ }^{43}$ He could seek to accomplish this end by contracting with independent retailers and subjecting them to various vertical restrictions, ${ }^{44}$ but franchising or full vertical integration will often be a less costly means of

37 See L. Rubin, supra note 30 , at 1,85 .

38 J. Batn, Industrial Organtzation 380-81 (1968); F. Scherer, Industriat. Market Structure and Economic Performance 78 (2d ed. 1980); L. Rubin, supra note 30 , at $29-31$.

39 See L. Rubin, supra note 30, at 31-33.

${ }^{40} \mathrm{See}$, e.g., Williamson, The Economics of Antitrust: Transaction Cost Considerations, 122 U. PA. L. Rev. 1439, 1450-63 (1974); Williamson, The Vertical Integration of Production: Market Failure Considerations, 61 AM. Econ. Rev. 112 (I971). The importance of transaction cost considerations in explaining vertical integration is also emphasized in L. Rubin, supra note 30, at 36-40.

${ }^{11}$ See Williamson, The Economics of Antitrust: Transaction Cost Considerations, 122 U. PA. L. REv. 1439, 1444-47, 1450, 1454-56 (1974). (1963).

42 E. Lewis \& R. Hancock, The Franchise System of Distrubution 7

43 The desire of some producers to control presentation of the product at the retail level in order to maintain or expand demand is noted in L. Rubin, supra note 30 , at 43 .

44 See generally $\mathrm{R}$. POSNER, supra note 1 , at 147-51. 
organizing distribution due to the problems inherent in dealing with an independent retailer. ${ }^{45}$

Once the decision is made to integrate forward into distribution, the entrepreneur must decide whether he will control the retail or wholesale facilities himself or franchise them to others. Most choose to franchise. In 1973, franchising represented about thirty percent of total retail trade, whereas manufacturers' sales through wholly owned stores represented only about two percent of such trade.48

Two reasons help account for the dominance of franchising. First, franchising may enable a franchisor to obtain the use of the franchisees' available capital. ${ }^{47}$ This may be an attraction to an entrepreneur who is unable to raise the capital for a new venture either internally or at an attractive interest rate in the capital market. An entrepreneur may lack a sufficiently established reputation on which potential lenders can base their confidence, and may thus be unable to borrow capital funds except at very high interest rates. ${ }^{48}$ In such circumstances, franchising may be an attractive way to raise capital.

This capital-raising potentiality of franchising may also appeal to entrepreneurs who wish to shift some of the risk of establishing new outlets to franchisees. ${ }^{49}$ To the extent that a franchisee invests his own funds in the new outlet, he bears the risk of the enterprise. Thus, the franchisor, by requiring franchisees to invest some capital, enables himself to expand into areas where the demand for his product is uncertain at less risk to himself. ${ }^{.0}$

45 See Williamson, Assessing Vertical Market Restrictions: Antitrust Ramifications of the Transaction Cost Approach, 127 U. PA. L. REv. 953, 969-72 (1979). $46 \mathrm{~L}$. Rubin, supra note 30 , at 1 .

47 This is a frequently mentioned explanation of the growth in franchising. See, e.g., E. Lewis \& R. Hancock, supra note 42, at 14-15; U. OzanNE \& S. HunT, supra note 30 , at $80-81$; L. Rubin, supra note 30 , at 56-57. But see Rubin, The Theory of the Firm and the Structure of the Franchise Contract, 21 J.L. \& EcoN. 223, 225-26 (1978).

48 Williamson has suggested that lenders may be cautious in lending funds to an inexperienced entrant into a new field due to lack of knowledge concerning the new entrant's qualifications and fears that the new entrant will misrepresent his chances of success. See Williamson, supra note 41, at 1457-78. The same concerns might influence lenders who are faced with a firm that has enjoyed limited success in one or several geographic markets and seeks to greatly enlarge the scope of its operations. Banks may in general charge higher rates to those who lack established reputations.

49 Of course, if the franchisor contributes the major portion of the initial investment, as is often the case, this explanation of franchising becomes less important.

50 The price the franchisor pays for this reduction in risk is the difference between the expected return to his capital if invested in the new outlet and its expected return in the best alternative investment. 
Second, franchising is a system for organizing production which combines the incentives of a small proprietorship with the scale economies of a large firm. ${ }^{51}$ As the number of a firm's retail outlets or distributorships grows, centralized management becomes more and more difficult. The firm thus has an incentive to grant increased authority to its local managers. ${ }^{52}$ As such authority is delegated, however, the firm is faced with a second problem-providing local managers with an incentive to manage their operations in the most efficient manner. In most cases, the best solution to this problem is to manage distribution through a franchisee rather than through one of the firm's own managers, ${ }^{, 3}$ because a salaried manager's incentive to operate the outlet efficiently is less than that of a franchisee, whose earnings depend directly upon the success of the outlet. This arrangement also benefits the franchisee by enabling him to profit from the franchisor's management expertise and its economies of scale in advertising, research and development, and purchasing.. ${ }^{54}$ For example, a new franchisee may learn to manage his enterprise competently at less cost through lessons from the franchisor than through trial and error.

Capital raising seems to be an important motivation for the use of franchise systems of distribution, at least during the parent firm's early stages of growth. 55 This explanation, however, cannot fully explain the growth in franchising. McDonald's Corporation, for example, appears to be primarily concerned with obtaining franchisees who will be good managers, ${ }^{58}$ not with raising capital or

51 See McCarthy, Trademark Franchising and Antitrust: The Trouble with Tie-ins, 58 Calfr. L. Rev. 1085, 1087 (1970). See also E. L.ewis \& R. Hancock, supra note 42, at 14-15; U. OzanNe \& S. HuNT, supra note 30 , at $80-81$; L. Rubin, supra note 30 , at 47-56 (evaluating this explanation from the vantage point of the theory of bureaucracy).

62 Management decentralization may enable firms to offset management diseconomies resulting from large firm size and thus enable them to exploit any available economies of scale in other fields. See F. Scheren, supra note 38, at 85-88. Such management diseconomies may be explained by the information distortion resulting from a large number of hierarchical levels within one organization. See Williamson, Hierarchical Control and Optimum Firm Size, 75 J. PoL. EcoN. 123, 126 (1967).

53 Cf. text accompanying note 46 supra (comparing franchises with whollyowned stores).

54 Cf. L. Rubin, supra note 30, at 30-33 (discussing the importance of economies of scale of various types in franchising systems).

55 U. Ozanne \& S. HunT, supra note 30 , at 82 , report that many fast food franchisors would prefer to own all the stores themselves but are unable to do this because of lack of capital. The source of this evidence was an opinion survey of fast food franchisors. The authors also note that capital problems may decrease over time. Id. 81 .

s6 Principe v. McDonald's Corporation, 631 F.2d 303, 310 (4th Cir. 1980). McDonald's selects and purchases the site and constructs the building for each new 
sharing risk. Apparently, as the franchisor grows, the need to obtain risk capital diminishes and the desire to obtain highly motivated management increases. ${ }^{57}$

\section{The Social Benefits of Franchising}

The foregoing discussion permits an estimation of the social benefits attributable to franchising. First, economic efficiency ${ }^{88}$ is promoted. To the extent that franchising reduces the management problems of vertical expansion, the total resource cost of providing a good or service to consumers is reduced. As this Comment has previously suggested, many goods and services cannot be effectively marketed unless the producer has a sufficient degree of control at the retail level to ensure uniformity in the marketing of the product. ${ }^{59}$ Franchising will often be the most efficient way to achieve this control because it allows the enterprise to take advantage of existing scale economies and at the same time provides efficiency-promoting incentives for the local managers. ${ }^{.0}$ In addition, consumers benefit because the increased availability of stores of standardized quality bearing a common trademark reduces the cost of identifying a store with products of acceptable quality. ${ }^{61}$ As a result of these cost savings, resources are freed to be used elsewhere in the economy and efficiency is thus promoted. Efficiency is also promoted if franchising reduces the risk and capital problems associated with vertical expansion, because these problems interfere with the flow of resources to their most valuable uses. ${ }^{82}$

In addition to its efficiency-enhancing properties, franchising produces social benefits consonant with the traditional antitrust

outlet. Id. 305-06. The company then selects franchisees "primarily on the basis of their willingness to work for the success of their operations." Id. 310 .

57 See note 55 supra. The Dunkin' Donuts chain employs a similar system. See Ungar v. Dunkin' Donuts of Am., Inc., 531 F.2d 1211, 1214 (3d Cir.), cert. denied, 429 U.S. 823 (1976).

58 As used in this Comment, efficiency means the use of economic resources in a manner that maximizes human satisfaction as measured by willingness to pay for goods and services. See generally R. POSNER, ECONOMIC ANALYSIS OF Law 10-11 (2d ed. 1977).

59 See notes 42 \& 43 supra \& accompanying text.

60 See notes 51 \& 52 supra \& accompanying text.

61 See F. ScHERER, supra note 38 , at 378.

62 See generally Arrow, The Organization of Economic Activity: Issues Pertinent to the Choice of Market Versus Nonmarket Allocation, in 1 SuBConamrtreE on Economy in Government, Joint Economuc Commottee, 91st Cong., Ist Sess., The Analysis and Evaluation of Public Expendrture: The PPB System 47, 54-56 (Comm. Print 1969). Cf. R. Posner, supra note 58, at 9-10 (referring to "the tendency of resources to gravitate toward their most valuable uses if voluntary exchange-a market-is permitted."). 
goals of preserving business opportunities for small entrepreneurs and decreasing concentration of economic power and centralization of economic decisionmaking. ${ }^{63}$ Franchising has been described as "the last frontier for the small businessman." ${ }^{44}$ One study has estimated that between thirty-six and sixty-eight percent of all franchisees would not be independent businessmen if franchising opportunities were not available. ${ }^{65}$ In addition, franchising, because it allows exploitation of any scale, transaction-cost, or distribution economies, provides an alternative to full vertical integration. ${ }^{68}$ Several courts ${ }^{67}$ and commentators ${ }^{68}$ have noted this choice of alternatives and the possibility that, by making franchising more difficult and costly, society runs the risk of encouraging vertical integration.

\section{The Economic Rationale of Franchise Tie-Ins}

\section{A. Why Franchisors Use Tie-Ins: The Metering Theory}

The preceding discussion has suggested that the franchising industry promotes important economic and social goals. This Comment now turns to considering whether the primary effect of per se illegality of franchise tying arrangements is to prevent the extension of market power, as suggested by the courts, ${ }^{69}$ or to hamper the efficient operation of franchising systems and thus reduce their size and the level of social benefits that flow from them.

63 See, e.g., Ungar v. Dunkin' Donuts of Am., Inc., 531 F.2d 1211, 1222-23 (3d Cir.), cert. denied, 429 U.S. 823 (1976); Susser v. Carvel Corp., 206 F. Supp. 636, 640 (S.D.N.Y. 1962), aff'd, 332 F.2d 505 (2d Cir. 1964); Baker, supra note 1, at 1281-82; Bohling, Franchise Terminations Under the Sherman Act: Populism and Relational Power, 53 TEx. L. Rev. 1180, 1181 (1975).

64 Distribution Problems Affecting Small Business: Hearings on S. Res. 40 Before the Subcomm. on Antitrust and Monopoly of the Senate Comm. on the Judiciary, 89th Cong., Ist Sess. 497 (1965) (remarks of Sen. Hart).

65 U. OzANNE \& S. Hunt, supra note 30 , at 113-14.

66 See L. Rubin, supra note 30 , at $46-47$; notes $51-54$ supra \& accompanying text.

67 See, e.g., Kentucky Fried Chicken v. Diversified Packaging Corp., 549 F.2d 368, 379 (5th Cir. 1977); Ungar v. Dunkin' Donuts of Am., Inc., 531 F.2d 1211, 1222-23 (3d Cir.), cert. denied, 429 U.S. 823 (1976).

68 See, e.g., Baker, supra note 1, at 1281-82; Hunt, The Socioeconomic Consequences of the Franchise System of Distribution, 36 J. MARKETING 32, 33-35 (1972), cited in Ungar v. Dunkin' Donuts of Am., Inc., 531 F.2d 1211, 1222-23 (3d Cir.), cert. denied, 429 U.S. 823 (1976); Comment, Franchise Tie-Ins and Antitrust: A Critical Analysis, 1973 WIs. L. Rev. 847, 875.

Vertical integration as an alternative to costly franchising is rendered less likely if the producer's goods are usually sold through retail outlets which also offer the goods of other producers and numerous types of other products. See Williamson, supra note 45 , at 979-80.

69 See note 10 supra \& accompanying text. 
The answer to this question turns on an examination of the purposes and effects of franchise tie-ins.

In an early case, the Supreme Court recognized that a tie-in may benefit purchasers of the tying product by reducing the initial offering price of that product. ${ }^{70}$ A person considering purchase of a fast-food franchise will not pay more than the total value he expects to receive from use of the franchise. This is true whether the franchisor attempts to collect his price through one large royalty payment at the outset or through a markup on supplies he requires his franchisees to purchase, ${ }^{71}$ because the prospective franchisee, in evaluating the price of the franchise, can be expected to take into account any markup he must pay on the tied product. ${ }^{72} \mathrm{~A}$ franchisor who requires franchisees to agree to a tying arrangement must therefore concede a reduced price for the trademark license to the extent of the markup on the tied product. ${ }^{73}$ Because of these constraints on his pricing discretion, a franchisor cannot use a tie-in to extend market power from the tying-product market to the market for the tied product. ${ }^{74}$

Why then do franchisors use tying arrangements? In some cases, use of a tying arrangement may result in certain production economies. $^{75}$ In other cases the tie-in may be a quality control measure used to protect the goodwill of the franchisor's trademark: ${ }^{76}$ requiring franchisees to purchase the product from the franchisor insures that they do not use inferior substitutes. Probably the best explanation, however, is that a tying arrangement is the most efficient way for a franchisor to collect the maximum amount that each franchisee would pay for use of the trademark if each franchisee could accurately estimate his future return from

70 Henry v. A.B. Dick Co., 224 U.S. 1 (1912).

71 See generally R. Posner \& F. EASTERbrook, AntTtrust: CaSes, Economac Notes, aND Other Materials 802-04 (2d ed. 1981). See also Baldwin \& McFarland, supra note 1, at 768; Bowman, supra note 1, at 24.

$7^{2} \mathrm{See}$, e.g., Baldwin \& McFarland, supra note 1, at 768; Bowman, supra note 1 , at 21 .

73 See note 72 supra.

74 The only exception to this statement is the possibility that the tie-in is being used to create an entry barrier. Such a barrier will not increase the seller's immediate profit but it will enable the firm to retain its market power over a longer period and thus increase its long-run profit potential. The entry barrier problem is discussed at notes 123-37 infra \& accompanying text.

75 See L. Sullivan, supra note 5, at 449; Bowman, supra note 1, at 29. This appears to have been the basis of the decision in Principe v. McDonald's Corp., 631 F.2d 303 (4th Cir. 1980), discussed at notes 164-68 infra \& accompanying text. 27-28.

76 See, e.g., R. PoSNER, supra note 1, at 175-76; Bowman, supra note 1, at 
the enterprise at the time of purchase. ${ }^{77}$ In such cases, the tied product serves as a counting or metering device, in that the more patronage the franchisee receives, the greater will be his demand for the tied product. ${ }^{78}$

A franchisor could accomplish the same result by estimating ex ante the maximum amount each franchisee would pay for the trademark and charging that amount outright as the total cost of the franchise. Alternatively, the franchisor could charge a low initial payment plus royalities calculated as a percentage of sales receipts. ${ }^{79}$ The first possibility, however, unrealistically assumes that the franchisor possesses perfect knowledge of his franchisee's individual demand curves. ${ }^{80}$ This arrangement would also give franchisees a strong incentive to understate, if asked, the value they expect to receive from their new franchises. ${ }^{81}$ Additionally, a franchisee is likely to be risk averse, which would lower the amount of money he would be willing to invest initially below the franchise's value in the absence of risk. 82

The second possibility suffers from a similar difficulty. If the franchisee is required to pay royalties as a percentage of his total sales, he has an incentive to distort the reported amount of such sales. Because of this problem, the franchisor would have to police his franchisees, and the costs of such policing efforts would lower his profits.

A tying arrangement is likely to be the most attractive alternative to a franchisor because it enables him to maximize his profits

77 The use of the tied product to collect revenue from the sale of the tying product was suggested in Bowman, supra note 1 , at 23-24, and elaborated on in Burstein, supra note 1, and Markovits (pt. 1), supra note 1, at 1399-1443.

Studies of the franchising industry support the idea that revenue collection is the primary purpose of most franchise tying arrangements and that quality control is a secondary motivation. These studies suggest that the franchisors rely on the tied product sales for a substantial amount of their income and that the tied product prices are higher than should be expected. See E. LewIS \& R. HaNcock, supra note 42, at 28-33; U. OZANNE \& S. HuNT, supra note 30 , at 47, 162. The revenue collection hypothesis seems to explain these findings better than the quality control hypothesis.

78 It is assumed here that the tied product is used in proportion to the franchisee's revenues. See text accompanying notes $115-20$ infra.

79 This solution has been suggested by courts that oppose tying as a means of revenue collection. 'See note 110 infra \& accompanying text.

so See O. Willmamson, MarkEts \& Hierarchmes $11-12$ (1975); Edwards, supra note 1 , at 93 .

81 Cf. Burstein, supra note 1 , at 72 ("Once the tying arrangement is agreed upon, the purchaser has an obvious incentive to 'cheat' insofar as he can obtain the tied goods on more favorable terms elsewhere. There is an inherent element of instability in these arrangements, an element of instability that calls for a continuous vigil on the part of the tying monopolist ....").

32 See Burstein, supra note 1 , at 72. 
by economizing on the costs of revenue collection. Use of the tied product as a counting device does not require an initial estimation of the value of the franchise to the franchisee, nor does it give the franchisee the opportunity to distort the amount of revenue he has earned or expects to earn. The franchisee must purchase the tied product in some proportion to his sales as long as the tied product is necessary to his operations. Of course, the franchisee may cheat and order supplies from someone other than the franchisor, but this type of cheating can be detected relatively easily in the course of the franchisor's quality control efforts. ${ }^{83}$

The leverage theory, which has been used as the primary rationale for condemning franchise tie-ins, ${ }^{84}$ is entirely inconsistent with this rationale for such tie-ins. Franchisors are not using tie-ins to create market power in the market for the tied product, but rather primarily to maximize their profits from the sale of the tying product. This theoretical observation is confirmed by an examination of the circumstances under which franchise tie-ins usually occur. In typical franchise tying cases, the franchisor could not reasonably have hoped to obtain any substantial market power with respect to the tied product. ${ }^{\mathrm{s5}}$

The revenue collection hypothesis is similar to the frequent suggestion that tying arrangements are primarily intended to permit the seller to engage in price discrimination. ${ }^{86}$ The discussion so far suggests, however, that even when a franchisor has no motive to attempt price discrimination, because all of his franchisees have similar earnings from, and hence demand for, their franchises, he will still have reason to use a tying arrangement to maximize his. profit from the sale of the trademark or franchise license. This

83 Cf. Note, Antitrust Problems in Trademark Franchising, 17 Stan. L. Rev. 926, 933 (1965) (discussing efficiencies of tying in quality control).

84 See Bowman, supra note 1 ; text accompanying note 10 supra.

85 See, e.g., Siegel v. Chicken Delight, Inc., 448 F.2d 43 (9th Cir. 1971), cert. denied, 405 U.S. 955 (1972); Cash v. Arctic Circle, [1980-1] Trade Cas. If 63,095 (E.D. Wash. 1979). These cases are discussed in note 171 supra and text accompanying notes 217-21 supra.

86 See, e.g., R. PoSNER, supra note 1, at 173-74; Bowman, supra note 1, at 24. If the franchisor is using the tying arrangement to price discriminate, he is in effect tailoring the price he charges each franchisee to the franchisee's ability to pay. Price discrimination may induce a monopolist to lower his marginal price and increase his output. See F. Scherer, supra note 38, at 320; O. WILLIAMson, supra note 80, at 11. But see R. POSNER, supra note 1 , at 177 (noting the absence of evidence that price discrimination increases output); L. SuLLrvaN, supra note 5, at 449-51. Sullivan notes that it is unclear whether price discrimination will bring in buyers at the lower end of the demand scale. Franchisors appear to believe, however, that charging a comparatively low initial fee and relying on subsequent royalties increases the number of franchises sold. See McCarthy, supra note 5l, at 1091. 
conclusion follows from the fact that, due to problems of risk aversion and uncertainty, the franchisee is unlikely to be willing to make a large initial payment. ${ }^{87}$ Indeed, neither the franchisor nor the franchisee may be able to estimate the sales level of the new operation with any accuracy. Furthermore, the franchisee is likely to distrust representations of profitability made by the franchisor. ${ }^{88}$ This combination of skepticism and risk aversion will tend to reduce the initial payment a franchisee will be willing to make. ${ }^{89}$ A franchisor thus has an incentive to develop a plan under which payments will be made in proportion to the actual profitability of the enterprise. Such a plan will increase the present value of the franchisor's expected earnings by providing for more efficient distribution of the risk of failure between the two parties. ${ }^{90}$

The franchisor could accomplish the same result by charging a large initial fee and providing in the contract for a rebate if the new facility is not as successful as expected. Negotiating and enforcing such a contract would be a costly process, however, due to problems of specifying the conditions under which the refund will be due and determining when those conditions exist. ${ }^{91}$ Furthermore, the franchisee will have less of an incentive to efficiently manage the enterprise to the extent that the franchisor will

87 See Burstein, supra note 1 , at $69-73$ (discussion of why risk and uncertainty may encourage the seller of a durable product to make use of tying arrangements).

88 This distrust stems not only from the assumed risk aversion of the franchisees, see E. LEwrs \& R. HANCock, supra note 42 , at 69 , but also from the way in which franchises are typically sold. Franchises are often purchased afier only brief contact between franchisor and franchisee. More importantly, the franchisor possesses most of the information concerning the potential profitability of the franchise. See id. See also U. Ozanne \& S. Hunt, supra note 30, at 38-39; Note, supra note 34, at 1029. For a technical explication of the economics of asymmetrically held information, see Akerlof, The Market for "Lemons": Quality Uncertainty and the Market Mechanism, 84 Q.J. Econ. 488 (1970).

89 See Burstein, supra note 1 , at 72.

${ }^{90} \mathrm{See} i d$. 69-73. In effect, the franchisor is insuring the franchisee against part of the risk of failure. The franchisor can better bear this risk because his investment is diversified over many franchises. See generally $\mathrm{K}$. ArRow, EssaYs IN THE THEORY OF RISK-BEARING 134-43 (1971).

91 Williamson, supra note 41 , at 1442-47, 1469-76, contends that uncertainty, small numbers exchange relations, opportunism, and the limited ability of human agents to manage complex information may make some long-term contracts difficult to negotiate and implement. These problems would be likely to arise in any attempt to negotiate and enforce a refund clause in a franchise agreement. For example, the parties would have to specify in the contract the level of effort the franchisee must put forth in order to entitle him to the refund in the event of failure. Because the franchisor could not effortlessly determine whether the franchisee was expending the required effort, he would be forced to continually monitor the franchisee's performance in order to protect against cheating. These costs could largely be eliminated by use of a tying arrangement, because a franchisee lacking the possibility of a refund in the event of failure would have greater incentive to manage the enterprise effectively. 
be unable to detect whether lowered profitability is due to poor management or to poor forecasting of consumer demand. For these reasons, a tying arrangement is a way to economize on the transaction costs involved in selling franchises.

A further reason for using a tying arrangement even in the absence of an intent to price discriminate is the likelihood that the franchisee will be unable to raise sufficient capital ${ }^{22}$ to both make an investment in the new enterprise, such as constructing the building or purchasing inventory, and make a large lump sum payment for the trademark license. If the franchisor is primarily interested in attracting good managers rather than raising capital, as the more mature firms may well be, ${ }^{93}$ it has an incentive to postpone the due date of payments. As the preceding analysis discloses, a tying arrangement is a convenient way to accomplish this. ${ }^{94}$

\section{B. The Benefits and Costs of Franchise Tying}

The foregoing analysis facilitates a determination of the true benefits and costs of franchise tying. This section will attempt such a determination with the aim of laying the groundwork for a proposed revision of the current per se rule against franchise tying.

\section{The Benefits of Franchise Tying}

Very few franchisors rely exclusively on an initial payment from their franchisees as their exclusive source of income.95 Most engage in some form of metering, either by charging royalities as a percentage of sales receipts or by selling goods and services to the franchisees, in order to increase their profits. ${ }^{96}$ Some franchisors rely entirely on such payments for their income. ${ }^{97}$ A likely explanation of this technique is that it enables the franchisor to sell more franchises than he could by charging a large initial license fee. ${ }^{98}$

92 See Comment, supra note 68 , at 848 .

93 See notes 56-57 supra \& accompanying text.

94 See text accompanying notes 75-85 supra.

95 See E. LEWIS \& R. HANCOCK, supra note 42, at 28-33; U. OzANNE \& S. HuNx, supra note 30 , at 47-49; L. Rubin, supra note 30 , at $64-65$. at 65 .

96 U. OzANnE \& S. HunT, supra note 30 , at $47-49$; L. Rubin, supra note 30 ,

${ }^{97}$ See McCarthy, supra note 57, at 1091.

98 See id. 1091 \& n.30. 
Permitting franchise tie-ins would enable franchisors to collect royalities in a way that is likely to be least costly to them. ${ }^{98}$ This would save resources which could then be used to produce additional goods, thus increasing the total value of goods and services produced in the economy. The resulting cost savings would also allow more franchises to be sold. This is so because a franchisor will only sell a franchise if he expects his total revenue from the sale, the sum of the initial and future payments, to equal or exceed the cost of supplying the franchise, ${ }^{100}$ with cost defined to include the services and training supplied to the franchisee, a satisfactory return on the franchisor's capital, and the revenue collection costs. If any of these costs are reduced, the franchisor will sell franchises from which he did not previously expect to receive sufficient revenue. ${ }^{101}$ As more franchises are sold, society benefits from increased management efficiency, the development of distributional systems of standardized quality, and increased opportunities and reduced risk of failure for small businessmen. ${ }^{102}$ Franchise tie-ins thus are likely to have substantial benefits which the law should not neglect.

\section{The Costs of Franchise Tie-Ins}

\section{a. Price Discrimination and Returns to Market Power}

Use of a metering tie-in enables a franchisor with market power ${ }^{103}$ to price discriminate among franchisees, because those franchisees who use more of the tied product will end up paying more for their franchises. The effect of this arrangement is that each franchisee pays the franchisor an amount approximating his

99 The franchisor asserted this claim in Mid-America ICEE, [1973-2] Trade Cas. I 74,681 (D. Or. 1973).

100 More precisely, the present value of his expected revenue must exceed the present value of his expected costs as defined in the text (and assuming risk neutrality).

101 These arguments are based on standard microeconomic theories of supply. See generally E. Mansfietd, Mraroeconomics 26-30, 34-35, 152-60 (3d ed. 1979).

102 See text accompanying notes 58-68 supra. Additional benefits will arise to the extent tie-ins reduce the costs of quality control. This Comment has contended that such cost reductions are a less likely explanation of franchise tie-ins than the desire to engage in inexpensive metering. For a different view leading to a similar result, see Baker, supra note 1 , at 1257-58, 1278.

103 A seller cannot profitably attempt to price discriminate among his customers unless he has some market power to give him some measure of control over price. F. SCHERER, supra note 38 , at 315 . 
individual valuation of the franchise. This increases the return to the franchisor's market power. ${ }^{104}$

One potential cost of increasing the returns available from the possession of market power is that other entrepreneurs will be encouraged to invest resources in obtaining and holding market power over the products they sell. ${ }^{105}$ Largely because of this concern, some commentators who agree with the price discrimination explanation of tie-ins have concluded that the present per se rule, although adopted for the wrong reasons, is nevertheless justified.106

Two persuasive reasons suggest, however, that this fear of encouraging attempts to acquire market power should not be considered a social cost of franchise tie-ins. First, high profits in an industry will normally attract entry of additional firms until prices are driven down to marginal cost. ${ }^{107}$ Hence, above-normal shortterm profits are no cause for special concern in the absence of barriers to entry, which are discussed below. ${ }^{108}$ Second, a franchise tying arrangement may serve a number of purposes that yield real resource savings yet do not necessarily allow the franchisor a higher than average rate of return. In particular, this Comment has suggested that tying arrangements are often used as a kind of deferred payment plan that helps overcome the franchisee's risk aversion, distrust of franchisor representations of profitability, and shortage of capital. ${ }^{109}$ Such a plan does enable the franchisor to earn a higher return than he could if he relied entirely on an initial payment for the franchise, but the source of these higher earnings is the elimination of inefficiency, not anticompetitive conduct.

In addition, it should be noted that per se prohibition of tie-ins would be an inadequate response to any such fear of encouraging expenditure of resources on the acquisition of market power. In several franchise tying cases, courts have suggested that price discrimination is permissible as long as it is not effected by means of a tying arrangement. ${ }^{110}$ Unless other forms of price discrimination

$104 C f$. R. PosNer, supra note 1 , at $173-74$ (illustrating how a tie-in used to price discriminate results in a correlation between the user's valuation and the price he pays).

105 See R. PosNer, supra note 1 , at 177.

${ }_{108}$ See Burstein, supra note 1; Ferguson, supra note 1.

107 For a discussion of the dynamics of entry, see F. Scheren, supra note 38, at 229-66.

108 See text accompanying notes 123-33 infra.

109 See text accompanying notes 86-90 supra.

110 See, e.g., Siegel v. Chicken Delight, Inc., 448 F.2d 43, 50 (9th Cir. 1971), cert. denied, 405 U.S. 955 ( 1972); Mid-America ICEE, Inc. v. John E. Mitchell Co., [1973-2] Trade Cas. $\llbracket 74,681$ (D. Or. 1973). This view is consistent with the observation that the price discrimination permitted by a tie-in will neither 
are also banned, the per se rule against tie-ins will not prevent price discrimination, but merely force franchisors to use a somewhat less efficient version, ${ }^{111}$ with a concomitant waste of resources and little, if any, reduction in incentives to attempt to acquire market power.

\section{b. Enforcement Inefficiency}

Professor Williamson has noted another potential problem in the case of tie-ins used for price discrimination: the cost of enforcing the tie-in may exceed the benefit the restriction confers, even though it does not exceed the extra income earned by the seller. ${ }^{112}$ Private gain in this case is not congruent with public benefit. In the case of franchise tie-ins, however, the tying arrangement can be enforced relatively inexpensively in the course of the already necessary quality control efforts. ${ }^{113}$ Furthermore, franchise tie-ins may be adopted precisely because they allow the franchisor to economize on certain efforts-maintaining quality control and selling franchises -in which it must engage regardless of any plan to price discriminate.11s Because of these two particular characteristics of franchise tie-ins, the enforcement cost problem noted by Professor Williamson will normally not arise in the franchise-tying context.

\section{c. Price Distortion}

Another potential economic cost of franchise tie-ins is the distortion in prices resulting from the excess of the price of the tied product over the opportunity cost of the resources used to produce it. ${ }^{115}$ This markup in the price of the tied product is necessary so that it may serve as a revenue-collection device. At the same time, however, the markup encourages the franchisee to substitute

enhance nor protect any market power possessed by a seller. See P. AREeDA \& D. TURNER, 3 ANTITRUST LAw I 733 d (1978).

The point made in the text undercuts an argument in Bauer, A Simplified Approach to Tying Arrangements: A Legal and Economic Approach, 33 VAND. L. REv. 283, 302-03 (1980), that a sufficient ground for holding tie-ins per se illegal is their effect of shifting resources from buyers to sellers. It is price discrimination, not the tie-in itself, that shifts resources. Because courts are willing to accept price discrimination, albeit without tie-ins, condemning tying arrangements because of their distributive effects misses the point.

111 For example, franchisors could tie royalty payments to sales receipts. See text accompanying notes 80-83 supra.

112 Williamson, supra note 41 , at 1447.

113 See note 31 supra \& accompanying text.

114 See notes 76 and 86-90 supra \& accompanying text.

115 See L. Rubin, supra note 30, at 34-36. 
other products for the tied product.110 If the prices of all inputs reflected their marginal costs prior to the imposition of the tie-in, this substitution would lead to inefficient production, since the rise in the price of the tied good would not reflect an increase in the actual resource cost of its production.117 This problem may be avoided if, for technological reasons, the franchisee must use the tied product in fixed proportion to other inputs, ${ }^{118}$ or if the franchisor requires the franchisee to use a production technique that requires use of a fixed proportion of the tied product.119 The franchisor may also spread the markup over a number of tied products in order to reduce the incentive to substitute away from the tied good. ${ }^{\mathbf{1 2 0}}$ These provisions, however, may make it more costly to police the franchise contract.

Furthermore, even if distortion were found to occur, it, like price discrimination, affords a poor justification for a per se rule or for treble damages or criminal liability. The franchisor is perfectly free to charge royalties as a percentage of sales, ${ }^{121}$ but if he does so distortion may be produced because the franchisee will have an incentive to produce less than he otherwise would.122 Here,

116 Id.

117 This point can be illustrated through a simple example. Assume the following:

Good $X$ Marginal Cost of Production

Price Under Tie-In $\$ 10$ $\$ 13$

Good $Y$ $\$ 12$

$\$ 12$

Assume also that prior to the tie-in the marginal cost equalled the price of the good to the franchisee, that marginal cost reflects the cost to society of producing the good, and that $X$ and $Y$ are substitutes. Good $X$ is the tied good.

Prior to the tie-in, the franchisee would buy good $X$. This is an efficient solution because production of $X$ costs less than production of $Y$. After the tie-in has been imposed, the franchisee is required to buy $X$, but at a higher price. Good $Y$ now is less expensive to the franchisee, but is still more costly to society. The consequent incentive for the franchisee to substitute $Y$ for $X$ is inefficient.

Another possibility is that the franchisee will continue to use the tied good but will alter his production function to use less of that input. See generally E. MANSFIELD, supra note 101, at 146-49.

118 L. Rubin, supra note 30 , at 36.

$119 \mathrm{Id}$.

120 In Bauer, supra note 5, at 303, the author argues that the use of multiple product tie-ins demonstrates that franchisors are attempting to obtain market power in the tied product markets because price discrimination could be achieved with only one tied product. Bauer does not explain, however, why a franchisor would benefit by obtaining monopolies over products used by his franchisees. The better explanation for this phenomenon is that by spreading the markup over several products the franchisor reduces the franchisees' incentives to engage in input substitution.

121 See note 110 supra \& accompanying text.

122 The franchisee will perceive the royalty fee as an addition to his marginal cost curve. He will thus produce less than if the royalties were charged as a lump sum payment. See Rubin, supra note 30 , at 65-66. 
as with the price discrimination rationale, liability would depend on how the undesirable effect was produced rather than on its existence.

\section{d. Entry Barriers}

A very serious objection to tying in general is the possibility that it might result in entry barriers. For example, Kaysen and Turner have argued that a tie-in will always raise an entry barrier in the market for the tied good to the same level as any entry barriers in the tying-product market, because a seller will have to supply both the tied and tying products "since he must be able to displace the whole package which the tying offers." ${ }^{123}$

Although adhered to by some, ${ }^{124}$ this view has been disputed by those who argue that such an entry barrier will arise only when the two products are complementary ${ }^{125}$ or when there are no reasonable substitutes for the tying product. ${ }^{126}$ In addition, it has been suggested that a tie-in will only raise an entry barrier if the elasticity of demand for the tied product is relatively low ${ }^{127}$ and the tied product market is so small relative to the available scale economies that the customers not covered by the tying arrangement will be too few "to support a sufficiently large number of efficient size producers to keep that general market effectively competitive and the price charged to the non-tied buyers at the competitive level." 128 Kaysen and Turner's view has also been criticized as invalid except in cases in which there are no uses for the tied good except in connection with the tying product. ${ }^{129}$

But even with these qualifications, the phenomenon that Kaysen and Turner pointed to may fail to satisfy the criterion for an entry barrier that most economists now employ. The definition of an entry barrier now generally accepted by economists is a cost that differentially affects a new entrant as compared with firms already

123 C. KAySEN \& D. Turner, supra note 5, at 157.

124 See, e.g., L. Suln.rvaN, supra note 5, at 447-48; Logic of Foreclosure, supra note 5, at 92-93. See also Baldwin \& McFarland, supra note 1 , at 773 ("The tying clause creates a barrier to entry. In most cases, it will increase the capital investment needed by a potential entrant, as he may have to produce a substitute for the tying product in order to enter the market for the tied product.").

125 Edwards, supra note 1 , at 98.

126 Pearson, supra note 1 , at 638.

127 Edwards, supra note 1 , at 99.

128 Id. (emphasis in original). See also Burstein, supra note 1, at 94 n.80; Pearson, supra note 1 , at 638 .

129 Ferguson, supra note 1 , at 563. 
in the market. ${ }^{130}$ That a new entrant into one field would also have to produce another product because of a tying arrangement would not necessarily produce such a cost differential, because the firm responsible for the tying arrangement would also have to supply both products. For this to constitute an entry barrier, producing both products would have to be more difficult for new entrants than for the existing producer.

The necessity for a new entrant to enter both fields simultaneously may constitute an entry barrier if the existing producer was able to enter one field initially and only later undertook to supply the second product. Such a new entrant may face higher capital costs because of lenders' uncertainty about the entrant's ability to perform if he lacks experience or a reputation for success in any field. ${ }^{131}$ A new entrant may also incur higher management costs in assembling the necessary skills to enter both fields simultaneously in the absence of "perfect fluidity of talent and resources." 132

Concerns about entry-barrier effects of tying arrangements are no more warranted in the franchising context than elsewhere, because it is unlikely that new entrants into either the tying or tied product market will have to enter both markets simultaneously. Most tie-ins will not pose entry barrier problems when franchisors are using them as metering devices or for quality-control purposes. If a franchisor is using a tie-in solely as a metering device, he will allow others to produce the tied product if they can do so more efficiently. ${ }^{133}$ If the tying arrangement is being used solely for quality-control purposes, the franchisor may insist on producing the product himself, but this will be because it is the most efficient way to protect the consumer goodwill associated with the franchise trademark, ${ }^{134}$ not because of predatory designs.

An entry barrier is only likely to arise when a franchisor uses a tying arrangement to pursue strategic objectives. The franchisor's control of production in the tied product market may then confront potential competitors with the prospect of having to simultaneously enter production of two products. ${ }^{135}$ Most tying arrangements do

130 Posner, The Chicago School of Antitrust Analysis, 127 U. PA. L. REv. 925, 945 (1979), citing G. Stigler, The Organization of INDUSTRY 67-70 (1968).

131 Williamson, supra note 41 , at $1456-58$.

132 L. SullivaN, supra note 5 , at 448.

133 R. POSNER, supra note 1 , at 175.

134 Id.

135 Consider the case in which a tie-in has enabled a franchisor to become the sole producer of the tied product. The franchisor's new competitors would then 
not in fact give sellers control of the tied product market. ${ }^{136}$ Nevertheless, the theoretical possibility does exist, and one recent case suggests that a tying arrangement may be used as part of a strategy to maintain a monopoly in the franchisor's product market. ${ }^{137}$ The entry barrier problem therefore should play some role in any new legal rule for franchise tying arrangements.

\section{e. Market Foreclosure}

Several authors have argued that tying arrangements should be condemned because they tend to reduce competition in the manufacture of the tied product, ${ }^{138}$ thus reducing pressures to develop more efficient methods of operation. ${ }^{138}$ The previous analysis has demonstrated, however, that only when a tying arrangement is used to create an entry barrier will it reduce the number or size of firms in the tied product market below that dictated by normal economic forces. ${ }^{140}$ This theoretical analysis is supported by the observation that many franchisors do use tied products which are manufactured by others. ${ }^{141}$ The desire to protect "competition on the merits" 142 in the tied product market is thus consistent with permitting franchise tying arrangements except in those cases in

be forced to produce the tied product as well if adequate substitutes were not available at reasonable prices, if the franchisor refused to sell the tied product to entrants at competitive prices, and if convergent-expectations problems prevented the simultaneous entry of new producers of the tied product. Convergentexpectations problems are noted in R. POSNER \& F. EASTERBRook, supra note 71, at 808, and are discussed more generally in Williamson, supra note 41 , at 1459-60.

136 See P. AREeda, ANTTtrust ANAlysts 570 (2d ed. 1974) ("Monopoly in the tied product is both rare and not often threatened by most actual tying arrangements.").

137 In Photovest Corp. v. Fotomat Corp., 606 F.2d 704 (7th Cir. 1979), cert. denied, 445 U.S. 917 (1980), the defendant sold camera products and film processing through franchised and company-owned drive-through kiosks. Id. 707. According to the appellate court, Fotomat intended to preempt the desirable sites for such kiosks nationally. Id. 715. The court also noted the district court's finding that Fotomat required its franchisees to lease the land and kiosks from the parent firm even though the franchisees were capable of finding suitable sites on their own or of purchasing them from the defendant. Id. 724-25. This tying arrangement may have been part of a strategy to deter entry by enabling Fotomat to maintain control of the sites to which potential competitors would be attracted. Control of these sites might have been lost if the sites had simply been sold to the franchisees.

138 See L. Sullivan, supra note 5, at 447; Bauer, supra note 5, at 298-99; Turner, supra note 5 , at 60-62.

139 See L. Sullivan, supra note 5, at 447.

140 See notes 133-35 supra \& accompanying text.

141 Bauer, supra note 5 , at 303.

142 Northern Pacific Ry. Co. v. United States, 356 U.S. 1, 6 (1958). 
which the practice is part of a strategy to maintain the franchisor's market position..$^{143}$

\section{f. The Loss of Free Choice}

From an economic perspective, loss of free choice is not a cost of franchise tying arrangements; by agreeing to the franchise contract the franchisee has indicated that the value to him of selecting alternatives to the tied product is less than the value of the package offered by the franchisor. Nevertheless, some authorities argue that free choice values are important in any legal analysis of the problem. Courts have indicated some fear that tie-ins may deprive purchasers of free choice between alternative sellers of the tied product. ${ }^{144}$ Professor Sullivan, expressing a similar view, has suggested that the present tying doctrine is based more on concerns about economic decentralization than on a desire to promote economic efficiency. ${ }^{145}$

Buyer free choice is, however, only one of the values that the present rule is designed to serve. It has never been seriously suggested that an infringement of free choice is by itself a sufficient ground on which to base an antitrust violation. ${ }^{146}$ In the context of franchising, allegations of loss of free choice may be based on a franchisee's desire to improve his position within a contractual relationship into which he freely entered.147 Without requiring coercion to be accompanied by an anticompetitive effect to constitute an antitrust violation, courts might become refuges for unhappy businessmen seeking solace in the pursuit of treble damages. ${ }^{148}$

143 One recent article attempts to show that the present law of tying arrangements is defective by arguing that this rationale for the tie-in prohibition-the desire to protect competition on the merits-was repudiated in the Supreme Court's recent decision in Continental T.V., Inc. v. G.T.E. Sylvania, Inc., 433 U.S. 36 (1977). Baker, supra note 1. This demonstration is unnecessary, however, because most franchise tie-ins will not distort production of the tied product. The most efficient producers of the tied product will prevail with or without the tying arrangement.

144 See note 12 supra \& accompanying text.

145 L. Sull.wan, supra note 5, at 448.

146 See Continental T.V., Inc. v. GTE Sylvania, Inc., 433 U.S. 36, 53 n.21 (1977). Cf. Turner, supra note 5, at 60-61 (arguing that the primary concern of courts in tying cases is probably with "free access" to the tied product market rather than with "free choice"); Logic of Foreclosure, supra note 5, at 92-93.

147 See Ungar v. Dunkin' Donuts of Am., Inc., 531 F.2d 1211, 1223 (3d Cir.) (dictum), cert. denied, 429 U.S. 823 (1976).

148 See Kestenbaum v. Falstaff Brewing Corp., 575 F.2d 564 (5th Cir. 1978):

Dealings between a manufacturer and its agents may be arbitrary, unfair, or lacking in good business judgment, but, without more, they will not violate the [Sherman] Act. The Sherman Act is not a "panacea for all business affronts which seem to fit nowhere else. ..." 
Infringement on franchisee free choice is thus a poor justification for a per se rule against franchise tying arrangements. In view of the Supreme Court's landmark decision in Continental T.V., Inc. v. GTE Sylvania Inc., ${ }^{149}$ it is also doubtful that free choice should be a significant factor in a rule of reason analysis of such arrangements. ${ }^{150}$ The Court held in Sylvania that non-price vertical restrictions imposed unilaterally by a manufacturer on its distributors were not per se illegal but were to be judged under a rule of reason. ${ }^{151}$ The Court noted that, although they may reduce intrabrand competition, vertical restraints are most often intended to improve the manufacturer's market position relative to that of competing manufacturers. ${ }^{152}$ Because a manufacturer can rarely abuse its ability to restrain intrabrand competition to attain objectives in the interbrand market, ${ }^{153}$ the Court indicated that the reasonableness of vertical market restraints may be judged by balancing the procompetitive and anticompetitive effects, ${ }^{154}$ even though it recognized that the freedom of independent retailers is restrained to some extent by such restrictions. ${ }^{155}$

The Court did not precisely define how its rule of reason approach should be applied. The opinion does suggest, however, that vertical market restrictions should be assessed by "balancing intrabrand and interbrand competitive effects," 156 and by placing emphasis on "market considerations." 167 Lower federal courts analyzing vertical restrictions in the light of Sylvania have focused

While the antitrust law has given more than a mere nod to the importance of business autonomy, respect for independence cannot justify finding a violation when no adverse impact on competition is shown. The Supreme Court has expressly rejected business autonomy as the basis for a per se rule against territorial restraints imposed on distributors who own the goods they sell. Followed to its logical conclusion, Kestenbaum's theory would subject a manufacturer to treble damage liability for any provision in a franchise agreement which turned out, in retrospect, to have been a bad business decision. This is not the purpose for which the Sherman Act was designed.

Id. 571-72 (citations omitted).

149433 U.S. 36 (1977).

160 See Baker, supra note 1.

151 Id. 58-59.

152 Id. 57-58.

153 Id. 52 n.19.

154 See, e.g., Gough v. Rossmoor Corp., 585 F.2d 381, 386-89 (9th Cir. 1978), cert. denied, 440 U.S. 936 (1979); Zelek, Stern \& Dunfee, A Rule of Reason Decision Model After Sylvania, 68 CAxIF. L. Rev. 13 (1980); Comment, Vertical Agreement as Horizontal Restraint: Cernuto, Inc. v. United Cabinet Corp., 128 U. PA. L. REv. 622, 635 (1980).

155433 U.S. at 46.

150 Id. 57 n.27.

157 Id. 53 n.21. 
on the economic effects of such practices rather than on free choice concerns. ${ }^{158}$ Sylvania and its progeny thus lend support to the view that franchise tying arrangements should be analyzed solely in terms of their effect on competition.

But even accepting the possibility that maximization of free choice should remain an important value in the antitrust analysis of tying arrangements, it is still doubtful that it affords a basis for condemning a franchise tying arrangement. By enabling franchisors to reduce their operating expenses, such arrangements may allow the firms to sell more franchises, ${ }^{159}$ thus providing some individuals with an option they would not otherwise have. Many persons become franchisees precisely because of their desire to increase their independence. ${ }^{160}$ The net effect of a tie-in on the level of individual autonomy is therefore uncertain, and to prohibit the practice on the basis of free choice concerns could have an effect opposite to the one intended.

IV. The Uncertainty and Inconvenience of the Present Rule

This Comment has shown that many franchise tie-ins promote economic efficiency by reducing transaction costs without greatly impinging upon, and in many cases promoting, the social goals of the antitrust laws. Only when a barrier to entry is created might anticompetitive effects outweigh efficiency gains.

These observations alone, however, merely raise another issue. The ability of the courts to effectively administer a new approach to tying arrangements must also be considered. One explanation offered for the courts' reluctance to consider the efficiency justifications of tie-ins is the difficulty they experience in evaluating economic arguments and their preference for the relative certainty and convenience of the present per se rule. ${ }^{101}$

The following discussion will suggest, however, that, although their importance often goes unacknowledged, economic concerns already intrude significantly into the law of tie-ins. Moreover, it will be shown that the present rule is not necessarily more certain or more convenient than a more lenient approach.

${ }^{158}$ See, e.g., Adolph Coors Co. v. A \& S Wholesalers, Inc., 561 F.2d 807, 813-14 (10th Cir. 1977); Newberry v. Washington Post Co., 438 F. Supp. 470, 474-75 (D.D.C. 1977). See also E. KnNTNER, supra note $23, \S 10.48$, at 218-19 (and cases cited therein).

159 See text accompanying note 101 supra.

160 E. LEwIS \& R. HANCOCK, supra note 42, at 17.

161 See Moore v. Jas. H. Matthews \& Co., 550 F.2d 1207, 1213 (9th Cir. 1977) (quoting Northern Pac. Ry. Co. v. United States, 356 U.S. 1, 5 (1958)), quoted in note 6 supra. 


\section{A. The Uncertainty and Inconvenience of the Present "Per Se" Rule}

\section{The Two Product Requirement}

The initial question in all tie-in cases is whether the tying and tied products are distinct or form a single package of items. ${ }^{162}$ Efficiency concerns play a large role here, although the courts usually articulate other rationales in their opinions. ${ }^{163}$

A recent example of this tendency is Principe v. McDonald's Corp. ${ }^{104}$ This case presented the question whether a franchisor was guilty of an illegal tie-in because franchisees were forced to lease their places of business from it. The court of appeals affirmed the district court's determination that no tying arrangement was involved because the franchisor was selling only a single package of goods and services. ${ }^{165}$ The court concluded that the practice of selling the lease and trademark license together was an essential factor in the franchisor's success and that it benefited the franchisees as well. ${ }^{166}$ This conclusion was based on a finding that the franchisor was able to obtain better sites than franchisees could select or acquire as a result of its scale economies and experience in franchising. ${ }^{167}$ The court's conclusion that no illegal tie-in existed was thus based on an efficiency defense even though the court's stated rationale was that the store lease was "not separable from the McDonald's franchise to which it pertains." 168

\section{The Market Power Requirement}

A plaintiff must also show that the defendant franchisor has sufficient economic power with respect to the tying product to appreciably restrain competition in the tied product market. ${ }^{169}$ In

162 See Fortner Enterprises, Inc. v. United States Steel Corp. (Fortner I), 394 U.S. 495, 507 (1969). See generally E. KINTNER, supra note 23, at 228-35; Levy, supra note 18.

163 See L. Sullrvan, supra note 5, at 449. See also Levy, supra note 18, at 51 n.52 (noting the existence of a business justification test).

164631 F.2d 303 (4th Cir. 1980).

165 Id. 305.

106 Id. 309-1I.

167 Id. 310.

168 Id. 309.

169 E.g., U.S. Steel v. Fortner Enterprises, Inc. (Fortner II), 429 U.S. 610 (1977); Ungar v. Dunkin' Donuts of Am., Inc., 531 F.2d 1211, 1223-24 (3d Cir.), cert. denied, 429 U.S. 823 (1976) (quoting Northern Pac. Ry. Co. v. United States, 356 U.S. 1, 6 (1958)). 
Siegel v. Chicken Delight, Inc., the Ninth Circuit abbreviated this inquiry into a franchisor's market power by presuming sufficient market power from the trademark on the tying product. ${ }^{170}$

If economic concerns were truly too cumbersome for judicial evaluation, one might expect other courts to follow this lead and avoid the need for a detailed inquiry into a franchisor's market power. The present trend, however, appears to be in the opposite direction.171 Other courts require the plaintiff to base its proof of a franchisor's market power upon a showing that the franchisor's trademark was so unique and desirable that the franchisor would be able to increase prices or force a significant number of buyers to accept burdensome terms. ${ }^{172}$ Under this type of inquiry, the complexities of market definition and market share continue to play an important role. 173 This type of complex inquiry weakens the present rule's claim to certainty and convenience.

170448 F.2d 43, 48-50 (9th Cir. 1971), cert. denied, 405 U.S. 955 (1972). Some courts have interpreted Siegel $v$. Chicken Delight, Inc., as resting on the economic power of the particular franchisor in that case. See, e.g., Cash v. Arctic Circle, Inc., [1980-1] Trade Cas. I 63,095 (E.D. Wash. 1979); Esposito v. Mister Softee, Inc., [1976-2] Trade Cas. I 61,202 (E.D.N.Y. 1976). Chicken Delight did indeed hold a preeminent position in the fast food industry, as the court of appeals recognized, 448 F.2d at 49 , but this was not the basis of the court's holding. The court's decision instead turned on its view of the registered trademark as a legal barrier to competition. Id. 50. The court in effect treated a trademark like a patent or copyright. Id.

171 In Cash v. Arctic Circle, [1980-I] Trade Cas. 163,095 (E.D. Wash. 1979), a district court refused to assign a presumption of economic power to trademarks, and distinguished Siegel v. Chicken Delight, Inc., 448 F.2d 43 (9th Cir. 1971), cert. denied, 405 U.S. 955 (1972), as relying on the market power of the particular franchisor in that case. [1980-1] Trade Cas. $\{63,095$, at 77,441-43. The defendant ice cream franchisor in Cash required its franchisees to purchase syrups and toppings from it as a condition of the trademark license. Id. 77,441. The franchisees' suit sought to recover the damages they suffered as a result of being forced to pay noncompetitive prices for the tied products. Id. 77,443 . In refusing to accept the presumption of economic power for trademarks, the court noted that a trademark only serves to prevent the piracy of trade names and the resulting deception of the public. Idd. 77,442 .

This is not the only example of a refusal to follow Siegel. The Second Circuit has consistently refused to assign a presumption of economic power to trademarks. See Capital Temporaries, Inc. v. Olsten Corp., 506 F.2d 658, 663-65 (2d Cir. 1974); Susser v. Carvel Corp., 332 F.2d 505 (2d Cir. 1964), cert. dismissed, 381 U.S. 125 (1965); Esposito v. Mister Softee, Inc., [1976-2] Trade Cas. I 61,202 (E.D.N.Y. 1976). Other circuits have similarly refused to base a finding of legally sufficient market power on a trademark alone. See Photovest Corp. v. Fotomat Corp., 606 F.2d 704, 725 (7th Cir. 1979), cert. denied, 495 U.S. 917 (1980); Northern v. McGraw-Edison Co., 542 F.2d 1336, 1346 (8th Cir.), cert. denied, 429 U.S. 1097 (1977); Carpa, Inc. v. Ward Foods, Inc., 536 F.2d 39, 48 (5th Cir. 1976).

172 Northern v. McGraw-Edison Co., 542 F.2d 1336, 1346 (8th Cir.), cert. denied, 429 U.S. 1097 (1977); Carpa, Inc. v. Ward Foods, Inc., 536 F.2d 39, 48 (5th Cir. 1976).

173 See, e.g., Photovest Corp. v. Fotomat Corp., 606 F.2d 704, 725 (7th Cir. 1979), cert. denied, 445 U.S. 917 (1980); Northern v. McGraw-Edison Co., 542 


\section{The Efficiency-Based New Industry and Goodwill Defenses}

Economic concerns have also modified the "per se" rule against tying arrangements through the establishment of the new industry and goodwill protection defenses. The new industry defense will save a tie-in from illegality if the tie-in is shown to be essential to protect the industry during its early stages of development. ${ }^{174}$ The defense is not a very significant one, however, because it operates only during an industry's early stages and requires the absence of any other suitable means of protecting the defendant's reputation..$^{175}$

The goodwill protection defense is of greater significance to franchising. It permits tie-ins that are necessary to the protection of the goodwill associated with the franchisor's trademark, unless an alternative arrangement, such as specifying the characteristics of the good to be used, is practicable. ${ }^{176}$ A less restrictive alternative will not be considered practicable if the tied product is too complex for a set of acceptable characteristics to be given to the franchisee. ${ }^{177}$

An economist would agree with the principles behind the new industry ${ }^{178}$ and goodwill defenses. ${ }^{179}$ Both defenses rest upon

F.2d 1336, 1346 (8th Cir.), cert. denied, 429 U.S. 1097 (1977); Cash v. Arctic Circle, [1980-1] Trade Cas. I 63,095, at 77,443 (E.D. Wash. 1979).

174 See United States v. Jerrold Elec. Corp., 187 F. Supp. 545 (E.D. Pa. 1960), aff'd per curiam, 365 U.S. 567 (1961).

175 See id. 556-57.

176 See, e.g., Kentucky Fried Chicken Corp. v. Diversified Packaging Corp., 549 F.2d 368, 376 (5th Cir. 1977); Carpa, Inc. v. Ward Foods, Inc., 536 F.2d 39, 46-47 (5th Cir. 1976). See generally E. KonTnER, supra note 23, at 257-61.

177 See Siegel v. Chicken Delight, Inc., 448 F.2d 43, 51 (9th Cir. 1971), cert. denied, 405 U.S. 955 (1972) (citing Standard Oil Co. v. United States, 337 U.S. 293,306 (1949)).

Professor Posner has criticized the courts' failure to give greater weight to the goodwill-protection defense. He contends that, by requiring suppliers to rely on quality specifications instead of tie-ins for quality control, courts may be fostering inefficient business practices. R. POSNER, supra note 1, at 175. See also Baker, supra note 1 , at 1249-51.

178 See, e.g., Williamson, supra note 45, at 965 :

[A]lthough [vertical restrictions] may be needed to ensure viability at an early stage in an industry's development, a more mature industry may be able to support the requisite distribution system without the same need for [such] restraints .... Thus, although forward integration may represent an effort to realize private gains with resulting economies at one stage, it may constitute an unneeded restraint at a later stage and indeed may serve strategically to disadvantage rivals if it is continued.

179 See Bowman, supra note 1, at 27; note 177 supra. 
cognizance of the free rider problem ${ }^{180}$ facing the franchisor in preserving the customer goodwill associated with its trademark. It would be a small additional step for courts to recognize that prohibiting tie-ins may force franchisors to adopt more costly alternatives to tying arrangements to enforce quality standards or collect revenue.

\section{The Individual Coercion Requirement}

The complexity of the present rule is further increased by the individual coercion doctrine. ${ }^{181}$ This requirement is a necessary product of the per se approach, which may encourage the franchisee "to sue for the treble damage windfall . . . regardless of the significance of the restraint and notwithstanding the fact that he paid no more than he would have paid in the form of a franchise fee." ${ }^{182}$ The coercion requirement attempts to alleviate this problem by insisting upon a showing that at least a modicum of pressure was exerted upon the franchisee in order to force him to accept the tie-in. ${ }^{183}$

Because evidence of coercion normally goes to show the existence of a tying arrangement, a formal tying agreement will usually obviate the need to show coercion. ${ }^{184}$ If, however, the contract does not require the purchase of the tied product, evidentiary problems are likely to arise. ${ }^{185}$ One court has found that proof of coercion could be based on indirect evidence, such as the existence of clearly burdensome terms coupled with economic power on the part

180 In a system of franchised retail or distribution outlets, each franchisee has an incentive to reduce the quality of service he provides below the optimal level, because the level of patronage he receives is determined by the reputation of the enterprise as a whole as well as by the reputation of his individual operation. Each franchisee thus has an incentive to "free ride" on the goodwill associated with the trademark, and the franchisor must engage in policing efforts to maintain uniform standards. Cf. R. PosNer, supra note 1, at 149-50 (discussing free rider problems in the context of restrictions on distribution). See also text accompanying note 31 supra.

181 See text accompanying notes 19 \& 28 supra. See generally Austin, supra note 1 .

182 Ungar v. Dunkin' Donuts of Am., Inc., 531 F.2d 1211, 1223 n.10 (3d Cir.), cert. denied, 429 U.S. 823 (1976). See also E. KInTNER, supra note 23, $\$ 10.59$ (and cases cited therein).

183 Bogosian v. Gulf Oil Corp., 561 F.2d 434, 450 (3d Cir. 1977), cert. denied, 434 U.S. 1086 (1978); Ungar v. Dunkin' Donuts of Am., Inc., 531 F.2d 1211, 1218, 1224 (3d Cir.), cert. denied, 429 U.S. 823 (1976).

184 See note I83 supra. But see Capital Temporaries, Inc. v. Olsten Corp., 506 F.2d 658, 665 (2d Cir. 1974) (holding that even a formal agreement incorporating a tie-in is not an illegal tying arrangement in the absence of proof that the licensee objected to the package); note 189 infra.

185 See E. KinTNER, supra note $23, \$ 10.59$, at 252-56 (and cases cited therein). 
of the seller. ${ }^{186}$ Other courts have required the plaintiff to show that he was actually forced or pressured into accepting the tie. ${ }^{187}$ It is sometimes not even clear to which aspect of the law the coercion requirement relates. Although it is usually discussed in the con, text of the question whether a tie-in exists, ${ }^{188}$ it may also influence the court's evaluation of the defendant's economic power. ${ }^{189}$

\section{B. An Appraisal of The Present Rule}

The theoretically straightforward ban against franchise tie-ins is thus not as simple as it first appears. Economic concerns, albeit in disguised form, seem already to have crept into the law. Furthermore, the present law may pose evidentiary problems that require detailed investigation, particularly in regard to assessing the defendant's market power and determining whether the plaintiff was coerced into the tie-in. The uncertainties surrounding the two product requirement, the market power test, and the new industry and goodwill defenses tend to reduce the predictability of the law as well as complicate the court's analysis. Indeed, it seems quite possible that the law would be clearer if efficiency concerns were acknowledged outright rather than being camouflaged behind such vague requirements as the two product rule.

It is necessary, however, to also acknowledge the limitations on the capacity of the courts to engage in economic analysis. What is needed, then, is an approach that incorporates fuller consideration of the actual effects of franchise tie-ins without significantly increasing the investigatory burden upon the courts.

\section{A NEW Approach}

\section{A. The Proposed Test}

Courts that have been confronted with revenue collection or quality control defenses to franchise tie-in illegality have generally refused to accept them, stating that less restrictive means are avail-

186 Moore v. Jas. H. Matthews \& Co., 550 F.2d 1207, 1216-17 (9th Cir. 1977).

187 Bogosian v. Gulf Oil Corp., 561 F.2d 434, 450-51 (3d Cir. 1977); Response of Carolina, Inc. v. Leasco Response, Inc., 537 F.2d 1307 (5th Cir. 1976); Ungar v. Dunkin' Donuts of Am., Inc., 531 F.2d 1211, 1224 (3d Cir.), cert. denied, 429 U.S. 823 (1976).

188 Bogosian v. Gulf Oil Corp., 561 F.2d 434, 450 (3d Cir. 1977); Ungar v. Dunkin' Donuts of Am., Inc., 531 F.2d 1211, 1224 (3d Cir.), cert. denied, 429 U.S. 823 (1976).

189 Bogosian v. Gulf Oil Corp., 561 F.2d 434, 451 (3d Cir. 1977) (citing Capital Temporaries, Inc. v. Olsten Corp., 506 F.2d 658 (2d Cir. 1974)). 
able to collect royalties or to protect the goodwill associated with the trademark. ${ }^{190}$ The preceding analysis has suggested that this approach is likely to lead to transaction-cost inefficiencies and thus make it more difficult to develop and operate franchise systems. ${ }^{101}$ At the same time, courts are unlikely to sanction all franchise tie-ins, and it is by no means clear that all franchise tie-ins are desirable. ${ }^{192}$ In particular, the courts need a test that is both manageable and capable of isolating those franchise tie-ins with potential anti-competitive effects. A typical rule of reason approach ${ }^{193}$ would throw open the gates to all concerns that ingenious counsel can think of. This Comment's proposal should be more useful to the courts.

One possible approach to formulating a workable test would be to incorporate all the potential costs and benefits of tie-ins discussed in this Comment. A number of these costs, however, have been shown to be of little significance in the franchise setting. ${ }^{194}$ Additionally, several of these potential costs would be difficult for courts to evaluate. For example, it would be very difficult for a court to determine whether a franchise tie-in is likely to increase the level of resources devoted to obtaining and holding market power. The court would first have to ascertain whether the tie-in was being used primarily as a metering device. ${ }^{195}$ Next, it would be necessary to decide whether the function of the tie-in was primarily to increase profits above the theoretical single price monopoly profit level or to distribute risk between the franchisor and franchisee. ${ }^{198}$ Finally, the court would have to ask whether the franchisor's price discrimination, where it was found to exist, primarily encouraged new entry into his product market or efforts to

100 See note 110 supra.

191 See notes 75-90 supra \& accompanying text.

192 For example, tie-ins may lead to substitution away from the tied product, see text accompanying notes 115-20 supra, or to erection of entry barriers, see text accompanying notes 123-37 supra. The potential distortion caused by tying arrangements is sometimes ignored by those advocating a change in the law. See, e.g., Baker, supra note 1.

193 See, e.g., Chicago Bd. of Trade v. United States, 246 U.S. 231, 238 (1918) (Brandeis, J.). But cf. National Soc'y of Professional Eng'rs v. United States, 435 U.S. 679 , 687-92 (1978) (advancing a rule of reason limited to inquiry into competitive effects).

194 See notes 103-14 supra \& accompanying text.

195 See text accompanying notes 77-78 supra.

196 For a diagrammatic comparison of the theoretical profits obtainable through single price monopoly and price discrimination, see Williamson, supra note 41 , at 1447-48. The theoretical distinction between metering to distribute risk and metering to price discriminate is discussed in notes 86-90 supra \& accompanying text. 
obtain monopolies in other fields. ${ }^{197}$ This would require intractable factual investigation. ${ }^{\mathbf{1 9 8}}$

The major potential anticompetitive effect of franchise tie-ins, and the easiest one for courts to evaluate, is the creation of a barrier to entry into the franchisor's product market. ${ }^{199}$ This problem is therefore the primary focus of the proposed test, which will now be summarized. The burden of proof for showing that the tying arrangement had created a potential entry barrier would be a part of the plaintiff's case. If this burden was met, and the defendant was unable to rebut the evidence presented, an anticompetitive effect would be presumed to exist. ${ }^{200}$ Because franchise tie-ins may also have procompetitive effects, the defendant would be permitted to show the beneficial aspects of the practice. If the court found that the arrangement had both pro- and anticompetitive effects, these would be balanced in accordance with the guidelines suggested below. ${ }^{201}$

The elements of the plaintiff's case under this approach can be incorporated within the framework of the present rule. First, the plaintiff would be required, as he is now, 202 to show that two distinct products exist. If the tying and tied products are such that they would ordinarily be produced or sold together because of economies of joint production or distribution, then the tie-in

197 See notes 103-08 supra \& accompanying text.

198 Courts would also find it very difficult to evaluate the distortion caused by an increase in the price of the tied product. Little distortion is likely to occur in most cases, because the franchisor has both the power and the incentive to prevent substitution for the tied product. See Rubin, supra note 30 , at 36 ; notes 118-20 supra \& accompanying text.

199 See notes 123-37 supra \& accompanying text.

200 Because most plaintiffs in franchise tying cases are franchisees, it would be impractical to require proof that entry actually had been deterred. The franchiseeplaintiff would often have no way of knowing if others had considered entry but had been deterred by high capital costs or the difficulty of assembling the managerial talent necessary to enter two industries simultaneously. See text accompanying notes 131-32 supra. The crucial concern should therefore be whether the franchisor's control of the tied product market would force a new entrant into one market to commence operations in the other field at substantially the same time. The likelihood that an entry barrier would result from the tying arrangement is a sufficient basis for antitrust scrutiny.

201 See text accompanying notes 212-16 infra.

This proposed test is similar to one suggested by Sullivan. L. Sulrivan, supra note 5 , at 452 . Sullivan, however, would require a showing, when a tie-in has been used to price discriminate, that the price discrimination "extended the use of the tied product and did no injury to resale competition." Id. The test proposed here concentrates instead on transaction cost economies and entry barriers.

Baker also suggests a relaxed approach to tying arrangements, see Baker, supra note 1, at 1317-19, but offers no specific guidelines for applying the rule of reason he advocates. The test proposed herein is more precise in its focus.

202 See note 162 supra. 
is merely the result of proper functioning of the competitive process and should not be prohibited.

Second, the plaintiff would be required to show that the franchisor possessed substantial economic power in the market for the good or service it retails. If the product is being sold competitively, the franchisor has no market power to protect by creating an entry barrier, and resource allocation will not be improved by encouraging entry into such a market. The requisite economic power would not be presumed because the good or service was trademarked; instead, the plaintiff would be required to show that the defendant's product was significantly differentiated from those sold by its competitors. ${ }^{203}$ Alternatively, the complainant could show that the franchisor's trademark was particularly desirable to potential franchisees, because the desirability of the trademark will normally reflect consumer preference for the good or service provided by the franchise system and thus indicate the franchisor's market power.

The substantial effect on commerce requirement would also be retained, but it, like the market power requirement, would be modified to make it more compatible with an entry barrier test. The plaintiff would be required to show that the tying arrangement had enabled the franchisor to control production of a substantial share of the tied product market. The meaning of "substantial" in this context should depend on the minimum scale at which the new entrant is required to operate. If one of the franchisor's potential competitors could initially open a small number of outlets and gradually build up his system, only a small amount of the tied product market would have to remain independent for the franchisor to escape liability. If, on the other hand, the

203 One recent article suggests that the Supreme Court adopted a low economic power threshold for tying products in U.S. Steel v. Fortner Enterprises (Fortner II), 429 U.S. 610 (1977). See Baker, supra note 1, at 1255-56. The assertion that the Court adopted "a minimal market power standard" in Fortner II, see id. 1248, is, however, inconsistent with the Court's statement that "the question is whether the seller has some advantage not shared by his competitors in the market for the tying product," 429 U.S. at 620 , and with the Court's concern that the defendant's product be "significantly differentiated" from the products offered by its competitors. Id. 622 .

Given these statements and the line of cases discussed in note 171 supra, a trademark by itself would seem to be an insufficient basis for a presumption of economic power. Although trademarks are often "associated intimately with the process of product differentiation," Baker, supra note 1 , at 1256 , they also serve other functions, such as encouraging quality-control efforts and reducing the time consumers must spend testing products subject to quality variations, F. SCHERER, supra note 38 , at 378 . A good or service may be trademarked and yet face substantial competition because a number of equally acceptable substitutes are available to consumers. The plaintiff under the proposed test would therefore be required to show the uniqueness of the franchisor's product. 
new entrant would have to build a large network of outlets quickly in order, for example, to develop consumer preference for the product or to take advantage of economies of scale, a larger share of the tied product market would have to remain independent. ${ }^{204}$ In addition, the speed at which independent producers of the tied product could expand the scale of their operations should be considered. If they could expand rapidly, no entry barrier exists even if a new entrant would have to start at a large scale.

By concentrating on the question whether the tying arrangement permits substantial control of the tied product market, the proposed test incorporates to some extent the concerns of those who believe that tie-ins will reduce competitive pressures in the tied product market. ${ }^{205}$ Thus, because the test does not require a showing that the practice was intended to create a barrier to entry, it condemns all tying arrangements that would give the franchisor control of the tied product market and would not have significant procompetitive effects. It is precisely such arrangements that are likely to reduce competitive pressures in the tied product market.

In contrast to the present law, ${ }^{208}$ a plaintiff franchisee under this test would not have to show that he was coerced into accepting the tying arrangement. If no anticompetitive effect was shown by the plaintiff, coercion need not be examined because liability would not result in any case. If a potential entry barrier was demonstrated and no redeeming procompetitive effects shown, the tie-in would be condemned because of its anticompetitive effects even in the absence of coercion.

If the franchisor is unable to rebut the plaintiff's evidence, he should be allowed to introduce other evidence to demonstrate the procompetitive effects of the tying arrangement. One way to approach this would be to allow the franchisor to introduce evidence of his transaction-cost savings and the resulting increase in his sale of franchises. The difficult task of directly estimating output, however, may exceed a court's capabilities. ${ }^{207}$ A better

204 One of the major advantages of franchising is that it may increase demand for the firm's product by providing a system of retail outlets that consumers can trust to be of uniform quality. See text accompanying notes $42-43$ supra. In order to expand demand in this way, however, the franchisor may need to operate on a large scale so that a substantial number of consumers will gain experience with the service or product that the firm provides.

205 See notes 138-39 supra \& accompanying text.

206 See text accompanying notes 181-89 supra.

207 Posner, The Next Step in the Antitrust Treatment of Restricted Distribution: Per Se Legality, 48 U. CFr. L. REV. 6, 21 (1981). Posner notes that exogenous variables may influence changes in the firm's output. 
approach would be for the court to examine the attributes of the particular franchise system and from these deduce whether it is likely that the tying arrangement has so reduced transaction costs that the franchisor can operate more efficiently and at a significantly larger scale. ${ }^{208}$

Several attributes of the franchise system should be considered by the court. The first is the geographical distribution of the franchises. To the extent that the franchises are spread out over a wide area, the franchisor can make use of a tying arrangement to economize on policing costs. ${ }^{209}$ A second characteristic to be noted is the relationship of the tied product to quality control. In one case, for example, an iced drink franchisor required its franchisees to purchase from it the drink-making machine that was identified with the franchisor's trademark, as well as some minor items such as cups. ${ }^{210}$ The former item is reasonably related to quality control; the latter is not. Also relevant to the court's inquiry are the amount of investment required of new franchisees and their average levels of business experience and available capital. The higher the total initial investment per franchise and the lower the new operators' capital and experience, the more likely it is that the franchisor is using the tying arrangement as a form of deferred payment plan that redistributes the risk of failure between franchisor and franchisee ${ }^{211}$ in order to economize on the efforts required to market franchises. Finally, the court should consider the extent to which franchisors with similar product lines have been able to operate successfully without the use of a tying arrangement.

In some cases, a court will find a franchise tying arrangement that allows the franchisor to produce all or most of the tied product but that does not yield significant operating economies. In such

208 Although such an approach may at first seem impractical or vague, it is very similar to the Fourth Circuit's analysis in Principe v. McDonald's Corp., 631 F.2d 303 (4th $\mathrm{Cir}$. 1980). The result reached in Principe provided a very reasonable solution to the competing interests at stake in that case.

209 The policing costs involved in both revenue collection and the maintenance of quality control are likely to rise if the franchises are distributed over a wide area, thus making the use of a tying arrangement more attractive from an efficiency standpoint.

210 Mid-America ICEE, Inc. v. John E. Mitchell Co., [1973-2] Trade Cas. I 74,681 (D. Or. 1973).

211 The theory of why a franchisor might wish to employ a risk distribution plan is discussed in the text accompanying notes 86-90 supra. One study has reported that franchisors tend to offer financial aid when a large investment by the franchisee is involved. See E. LEWIS AND R. HANCOCK, supra note 42, at 33. A tying arrangement is not the only way to collect revenue from the franchisees but it is likely to be the most practical means of doing so. See text following note 78 supra. 
cases, the tying arrangement should be prohibited because it creates a potential barrier to entry into the franchisor's field without an offsetting efficiency gain. The potential anticompetitive effect justifies holding the tie-in illegal even without a showing of actual harm because of the need to limit the scope of the court's inquiry, ${ }^{212}$ problems of proof, ${ }^{213}$ and the general antitrust policy of enhancing competition whenever it is not harmful to do so. ${ }^{214}$

In other cases, however, a court will be confronted with a tie-in that allows the franchisor to realize significant economies and thus increase the scope of his operations. In such cases the court should balance the procompetitive and anticompetitive effects of the tying arrangement. Thus, an effort must be made in these cases to determine whether the franchisor's control over production of the tied product is in fact a significant deterrent to its potential competitors. The relevant question here is whether the necessity of entering both markets simultaneously is likely to result in higher management or capital costs for a new entrant because of his lack of skill or reputation in one of the fields. ${ }^{215}$ Thus, the court should consider the probability that a potential producer of the franchisor's product would have the skills and reputation necessary to successfully produce the tied product as well.

If a court using this approach finds an actual entry barrier to exist, the tie-in should be prohibited. Not only does the entry barrier prevent new competition, but the insulation from competition is also likely to increase the level of the defendant's costs ${ }^{216}$ and thus offset the procompetitive aspect of the tying arrangement as well. In those cases in which the court doubts the existence of an actual entry barrier, the tying arrangement should be permitted. Either new competitors are free to enter the franchisor's product market or, if they are not, it must be because of something other than the tying arrangement.

Siegel $v$. Chicken Delight, 217 a leading franchise-tying case, would quite probably be decided differently under this test. The

212 See Moore v. Jas. H. Matthews \& Co., 550 F.2d 1207, 1213 (9th Cir. 1970) (quoting Northern Pac. Ry. Co. v. United States, 356 U.S. 1, 5 (1958)).

213 See note 200 supra.

214 See L. SullivaN, supra note 5, at 448.

215 See text accompanying notes 131-32 supra.

210 Costs may be increased either because managers released from competitive pressures are less interested in managing the enterprise efficiently or because the firm seeks to maintain its market power through increased expenditures on, inter alia, product differentiation, litigation, and political lobbying. See generally F. SchERER, supra note 38 , at 464-71.

217448 F.2d 43 (9th Cir. 1971), cert. denied, 405 U.S. 955 (1972). 
tied products in Siegel, which included cookers, fryers, batter and seasoning mixes, and packaging, ${ }^{218}$ were all items that a new fast food operator could have obtained from other producers. The tying arrangement thus did not create a barrier to entry into the fast food industry. Assume, however, that somehow entry into the fast food industry was inhibited by the tying arrangement. Little information is presented in the opinion concerning the scope of Chicken Delight's operations or the characteristics of its franchises. The fact that no initial fee was charged to the franchisees ${ }^{219}$ sug. gests, however, that the tying arrangement was used in part to deal with problems of risk and uncertainty. ${ }^{220}$ On the other hand, the opinion notes that other fast food franchisors similar to Chicken Delight did not use tying arrangements. 221 In view of this fact, the tying arrangement would probably not be justified by transactioncost savings if it created a potential entry barrier problem.

\section{B. Possible Objections to the Proposed Test}

One possible objection to the proposed test is that most franchise tie-ins will be permitted and, as a result, franchisees will be defenseless against parent firms that seek to collect far more in royalties than the franchisee expected to pay. Franchisees' frequent dismay at the limits on their income is a major source of conflict. $^{222}$ Nevertheless, the antitrust laws, which threaten treble damage liability and even criminal sanctions, ${ }^{223}$ are probably not the best way to handle this problem. Antitrust violations should be based on anticompetitive effects ${ }^{224}$ rather than on uneasiness with the behavior of franchisors. Of equal importance here is the fact that the two parties share a common interest. In particular, the franchisor depends on its franchisees to develop a market for its

218 Id. 46 n.1.

219 Id. 46.

220 Chicken Delight in effect leased its trademark for a variable rental which depended on the amount of business received by the franchisee. This is precisely the risk-reducing element of tying arrangements discussed in Burstein, supra note 1 , at 71 .

221448 F.2d at 48 n.4.

222 See Ungar v. Dunkin' Donuts of Am., Inc., 531 F.2d 1211, 1223 (3d Cir.), cert. denied, 429 U.S. 823 (1976).

22315 U.S.C. $\$ 1$ (1976).

224 See Brunswick Corp. v. Pueblo Bowl-O-Mat, Inc., 429 U.S. 477, 489 (1977) ("Plaintiffs must prove antitrust injury, which is to say injury of the type the antitrust laws were intended to prevent and that flows from that which makes defendants' acts unlawful.") (emphasis in original). 
products and maintain its accumulated consumer goodwill. 225 Thus, both parties have an incentive to adjust to each other's needs.

A second possible source of concern about the proposed test is that it may permit intentionally predatory conduct if it is shown to be justified by cost savings or if no anticompetitive effect results. A partial response to this concern is that attempts to monopolize are illegal under section 2 of the Sherman Act, ${ }^{226}$ and that tie-ins have been used as evidence of an attempt to monopolize. ${ }^{227} \mathrm{By}$ removing the issue of the intent of a tie-in from the court's consideration unless the plaintiff also alleges an attempt to monopolize, the proposed test eases the burden of the rule-of-reason approach on the courts. Additionally, few franchise tie-ins can be said to have only one purpose; indeed, they often serve a variety of functions. ${ }^{228}$ An intent-based inquiry would therefore probably be a futile exercise.

One might also question whether a separate rule should be created for franchise tying arrangements in view of the fact that they have traditionally not been singled out for such special treatment. A different approach for franchising is justified because most of the plausible explanations for the use of franchise tie-ins ${ }^{229}$ do not suggest serious anticompetitive effects. This cannot be said of tie-ins in general. For example, tying arrangements of products used in variable proportions may cause anticompetitive effects. ${ }^{230}$ Economic analysis may thus suggest different rules for tie-ins in different economic settings. ${ }^{231}$

225 E. LEThS AND R. HANCOCK, supra note 42 , at $6-9,67$. See also text accompanying notes $12-43$ supra.

22615 U.S.C. $\$ 2$ (1976). For a discussion of the attempt-to-monopolize offense, see L. SulLrvaN, supra note 5, at 134-40; Handler \& Steuer, Attempts to Monopolize and No-Fault Monopolization, 129 U. PA. L. Rev. 125 (1980).

227 See Photovest Corp. v. Fotomat Corp., 606 F.2d 704, 720 (7th Cir. 1979), cert. denied, 445 U.S. 917 (1980).

228 In Siegel v. Chicken Delight, Inc., 448 F.2d 43 (9th Cir. 1971), cert. denied, 405 U.S. 955 (1972), for example, the franchisor claimed that the tying arrangements were used for both quality control and revenue collection purposes. Id. 50-51.

229 See text accompanying notes 75-78 supra. 25-27.

230 Baldwin \& McFarland, supra note 1, at 769; Bowman, supra note 1, at

231 Although courts have traditionally applied the per se ban on tying arrangements to franchising without qualification, the Fourth Circuit referred recently to the "emerging law of tie-ins in franchise settings." Phillips v. Crown Central Petroleum Corp., 602 F.2d 616, 627 (4th Cir.), cert. denied, 444 U.S. 1074 (1980). The Supreme Court has expressed a reluctance to hamper the establishment of franchise systems by the use of per se rules. See Continental T.V., Inc. v. GTE Sylvania Inc., 433 U.S. 36, 57 n.26 (1977). Thus, some legal basis for a separate rule for franchising already exists. 


\section{Conclusion}

Courts confronted with economic justifications for tying arrangements have tended to reject them, claiming that these arguments are beyond judicial competence. Nevertheless, the costs of such refusals are significant if the result is substantially less efficient forms of enterprise organization.

This Comment has suggested that in the context of franchising the cost of this refusal to consider the economic rationales of tying arrangements is probably too great to ignore. The analysis has also shown that the costs and benefits of such arrangements are not difficult to understand. A more lenient approach to franchise tying arrangements should therefore be adopted.

The major advantage of this Comment's proposal is that it would allow society to reap many of the benefits of franchising that are now being sacrificed in the name of the per se prohibition of tying arrangements. A significant additional advantage of this Comment's proposal is that it would not impose upon the courts an administrative burden much, if at all, greater than under the present so-called "per se" rule. A court would have to examine in some detail the function of the tying arrangement in the operation of the franchisor's business if the plaintiff can show a potential entry barrier and the defendant attempts to show a procompetitive effect. This, however, would not require much additional inquiry beyond that currently required, because efficiency concerns ${ }^{232}$ and defenses ${ }^{233}$ are already part of the law. Moreover, the type of evidence that this Comment's proposal would require is not particularly complex or obscure. Indeed, when the elimination of the coercion requirement is considered, the overall cost of enforcement may be no more under the proposed new rule than under the current rule.

232 See text accompanying notes $161-80$ supra. 233 See text accompanying notes 174-80 supra. 